Review Articles

\title{
Recent Advances in Fabrication Techniques of Perovskite Solar Cells: A Review
}

\author{
Alborz Ehtesham, WeiWen Wong, H.Y. Wong and Mukter Zaman \\ Faculty of Engineering (FOE), Multimedia University, 63100 Cyberjaya, Malaysia
}

\author{
Article history \\ Received: 28-08-2016 \\ Revised: 25-10-2016 \\ Accepted: 25-11-2016 \\ Corresponding Author: \\ Mukter Zaman \\ Faculty of Engineering (FOE), \\ Multimedia University, 63100 \\ Cyberjaya, Malaysia \\ Tell: $+6010-5391581$ \\ Email: mukter@mmu.edu.my
}

\begin{abstract}
In this study, thorough review is performed on various reported fabrication techniques of the Perovskite Solar Cell (PSC) and the Hole Transport Materials (HTM) layer, in order to provide a critical insight on the direction for further advancement in related fields as well as a better understanding on the device physics. So far, the best short-circuit current density of $22.9 \mathrm{~mA} / \mathrm{cm}^{2}$ has been reported in $\mathrm{CH}_{3} \mathrm{NH}_{3} \mathrm{PbI}_{3-\mathrm{x}} \mathrm{Cl}_{\mathrm{x}}$ scaffold by $\mathrm{TiCl}_{4}$ nanorods treated by NRS and the best open circuit voltage of $0.763 \mathrm{~V}$ has been reported in $\mathrm{TiO}_{2} /$ perovskite/spiro-OMeTAD/Au. On the other hand, so far the highest PCE of the PSCs reported in the literature is $19.3 \%$. Interestingly, PSC with $200 \mathrm{~nm}$ mesoporous $\mathrm{TiO}_{2}$ has been reported to achieve PCE value of $16.46 \%$. A 5-layer $\mathrm{TiO}_{2} /$ perovskite/spiro$\mathrm{OMeTAD} / \mathrm{Au}$ integrated with $40 \mathrm{~nm} \mathrm{ZnO}$ thin film has been reported to achieve Fill Factor (FF) of $76 \%$. Although promising data has been obtained through numerous researches, there are still many other optimizations yet to be done before mass commercialization of PSC is possible. Optimizing the fabrication process of carrier transport material as well as the incorporation of sensitizer into the device structure are the key aspects that should be focused on in future researches.
\end{abstract}

Keyword: Perovskite, Solar Cell, Fabrication, Efficiency, Influence Effect, Replicable Energies

\section{Introduction}

Benchmarking of PSC Research and Development

Perovskite is a special type of solar cell material, named after the Russian mineralogist, L. A. Perovski (1792-1856) and is often considered as one of the most promising types of next-generation solar cell material. PSC has the perovskite crystal structure, which is shown in Fig. 1a and generally consists of organic and inorganic materials. The organic material converts solar energy to electrical energy, while the inorganic material provides the crystal structure. Generally, the PSC device is fabricated on top of a conductive substrate. The device structure consists of a layer of Electron Transport Material (ETM), followed by a perovskite sensitizer which converts photons into electrons and holes, a layer of Hole Transport Material (HTM) and finally the electrode layers to complete the circuit externally with the conductive substrate. A typical device structure of a PSC is shown in Fig. 1b. Despite the considerable amount of speculations that arose when PSC was first introduced in 2009, PSC is now considered to have a promising future because of its high energy conversion efficiency at lower cost than conventional solar cells, as well as its high versatility which allows it to be coated on various types of substrate materials. Although the commercialization progress of PSC is still currently in its infancy stage, its fabrication methods are found to be amazingly versatile, as there are many proven alternatives to fabricate PSC successfully.

In terms of energy conversion efficiency, PSC has been improving dramatically in the last few years. Researchers have demonstrated that the energy conversion efficiency of PSCs could go up to $20 \%$. Nevertheless, stability of PSC remains as a critical concern. While conventional silicon-based solar cells can last for up to a quarter century without significant degradation in its performance, PSC with the best performance reported so far is only capable to maintain optimal performance for up to $100 \mathrm{~h}$ (Alharbi et al., 2014; Peplow, 2014). The relatively poor stability of PSC is because perovskite compound, which is water soluble, would break down easily in the presence of sunlight. Therefore, the current challenge in the development of PSCs is the stability issue rather than performance issue. 


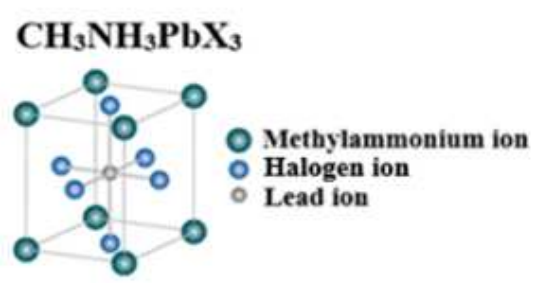

(a)

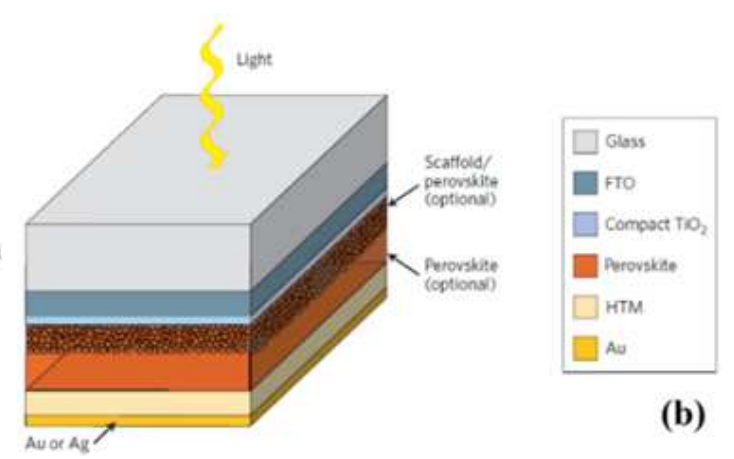

(b)

Fig. 1. (a) The crystal structure of perovskite (b) the structure of perovskite-based solar cell (Green et al., 2014)

In this review, the fundamental working principle of PSC will be discussed along with all the reported possible combinations of PSC components, followed by different fabrication techniques of the PSC and HTM layers, as well as the synthesis processes of the PSC components reported in the literature. A critical review on different reported conditions such as but not limited to various atmosphere condition, thin film properties, HTM, electron transport, external electric field, blocking layer, transport layer, $\mathrm{CBO}$ and $\mathrm{VBO}$ absorber layer, heat treated ion assisted film, thermal annealed effect, reduced graphene oxide, blade coating and low temperature solution will be provided systematically. This review would be useful to benchmark all the research activities for PSC in order to obtain an insight for future studies on related fields.

\section{Overview of Synthesis Methods of PSC}

Different types of perovskite can be fabricated in different methods, among which fabrication methods of $\mathrm{CH}_{3} \mathrm{NH}_{3} \mathrm{PbI}_{3}$ (iodine based), $\mathrm{CH}_{3} \mathrm{NH}_{3} \mathrm{Sn}_{0.5} \mathrm{~Pb}_{0.5} \mathrm{I}_{3}$, $\mathrm{CH}_{3} \mathrm{NH}_{3} \mathrm{SnI}_{3}, \quad \mathrm{CH}_{3} \mathrm{NH}_{3} \mathrm{PbBr}_{3} \quad$ (bromine based), $\mathrm{K}_{2} \mathrm{La}_{2} \mathrm{Ti}_{3} \mathrm{O}_{10}, \mathrm{La}_{0.7} \mathrm{Sr}_{0.3} \mathrm{MnO}_{3}$, hybrid PSC with a planar heterojunction structure have been reported as the most promising methods and will therefore be explained in this section. This section will end with a summary of the different fabrication methods discussed.

\section{Synthesis of $\mathrm{CH}_{3} \mathrm{NH}_{3} \mathrm{PbI}_{3}$ Sensitizer (Iodine-based)}

The most well-known perovskite compound is $\mathrm{CH}_{3} \mathrm{NH}_{3} \mathrm{PbI}_{3}$, which can be fabricated by mixing $\mathrm{PbI}_{2}$ and $\mathrm{CH}_{3} \mathrm{NH}_{3} \mathrm{I}$. In order to produce the $\mathrm{CH}_{3} \mathrm{NH}_{3} \mathrm{I}$ compound, methylamine $(30 \%)$ is mixed with $\mathrm{HI}$ $(45 \%)$ in ice-bath for few hours so that the chemicals can react effectively (Jeon et al., 2014). The solution also can be synthesized under nitrogen atmosphere at $0^{\circ} \mathrm{C}$ (Wang et al., 2015). After that, the evaporation of the methylamine and HI solvent will be conducted at high temperature. The remaining solid is dissolved in ethanol and recrystallized in diethyl ether. From this process, $\mathrm{CH}_{3} \mathrm{NH}_{3} \mathrm{I}$ compound which is pure-white in color (Xin et al., 2014; Sheikh et al., 2015) would be obtained. It can also be synthesized by adding $24 \mathrm{~mL}$ of methylamine and $10 \mathrm{~mL}$ of hydroiodic acid with $100 \mathrm{~mL}$ of ethanol with continuous stirring for $2 \mathrm{~h}$ in ice bath. With a help of rotary evaporator at $50^{\circ} \mathrm{C}$ to exclude the solvent, the precipitate is collected. Later on the product is recrystallized in ethanol and followed by the filtering and washing the end product with diethyl ether. Next step is drying for $24 \mathrm{~h}$ at $60^{\circ} \mathrm{C}$ in vacuum oven (Dkhissi et al., 2015; Li et al., 2015).

$\mathrm{CH}_{3} \mathrm{NH}_{3} \mathrm{PbI}_{3}$ can be fabricated by dissolving $\mathrm{CH}_{3} \mathrm{NH}_{3} \mathrm{I}$ and $\mathrm{PbI}_{2}$ in gamma-butyrolactone and maintaining uniform stirring for $24 \mathrm{~h}$. Next, the solution is deposited on top of the substrate by spin coating and heated up for $30 \mathrm{~min}$ at $100^{\circ} \mathrm{C}$. Another method to synthesize $\mathrm{CH}_{3} \mathrm{NH}_{3} \mathrm{PbI}_{3}$ is by dissolving $\mathrm{PbI}_{2}$ in $\mathrm{N}, \mathrm{N}$ dimethylformamide at $70^{\circ} \mathrm{C}$ (Zhang et al., 2015) and then spin coating it on top of the substrate. The layer is then dried by heating the substrate at $70^{\circ} \mathrm{C}$ for $15 \mathrm{~min}$. Then, the substrate is dipped into 2-propanol solution that contains $\mathrm{CH}_{3} \mathrm{NH}_{3} \mathrm{I}$ to form $\mathrm{CH}_{3} \mathrm{NH}_{3} \mathrm{PbI}_{3}$ layer (Della Gaspera et al., 2015). Another method to fabricate perovskite $\mathrm{CH}_{3} \mathrm{NH}_{3} \mathrm{PbI}_{3}$ is by adding $30 \mathrm{~mL}$ of hydrochloric acid with methylamine and stirring the solution without any interruption for $2 \mathrm{~h}$. Then, the precipitates of $\mathrm{CH}_{3} \mathrm{NH}_{3} \mathrm{I}$ are collected by distillation at $50^{\circ} \mathrm{C}$ under reduced pressure and washed with diethyl ether. Next, the precipitates are recrystallized using ethanol and diethyl ether and dried in a vacuum oven at $70^{\circ} \mathrm{C}$ for $24 \mathrm{~h}$. The purified $\mathrm{CH}_{3} \mathrm{NH}_{3} \mathrm{I}$ powder is dissolved in gamma-butyrolactone with $\mathrm{PbI}_{2}$ overnight at $60^{\circ} \mathrm{C}$ with continuous stirring to form the precursor (Xiao et al., 2014). In addition to the perovskite structure, another compound, known as $\mathrm{CH}_{3} \mathrm{NH}_{3} \mathrm{PbI}_{3-}$ ${ }_{\mathrm{x}} \mathrm{Cl}_{\mathrm{x}}$, has been reported in similar context. It can be fabricated with Methylamine Iodide (MAI) to $\mathrm{PbCl}_{2}$ molar ratio of 3:1, where the mixed solution is stirred for $24 \mathrm{~h}$ at $60^{\circ} \mathrm{C}$ and then added into the prepared $\mathrm{CH}_{3} \mathrm{NH}_{3} \mathrm{PbI}_{3}$ (Wang et al., 2015; Sheikh et al., 2015).

Several performance curves of the $\mathrm{CH}_{3} \mathrm{NH}_{3} \mathrm{PbI}_{3}$ PSC with varying film thicknesses, when illuminated from the 
FTO side, are shown in Fig. 2. From the I-V curve $\mathrm{CH}_{3} \mathrm{NH}_{3} \mathrm{PbI}_{3} \mathrm{PSC}$ with $290 \mathrm{~nm}$ film thickness is reported to have the highest current density compared to PSC with other film thicknesses. At the same time, the 290 $\mathrm{nm}$ PSC also showed highest IPCE and lowest transmittance at wavelength ranging from 550 to $800 \mathrm{~nm}$ (Della Gaspera et al., 2015).

\section{Synthesis of Cocktail PSC}

The substrate material used to fabricate cocktail perovskite is FTO glass/compact. First, the patterning and cleaning of the substrate is carried out. Then, by using spray pyrolysis method titanium(IV) cetylacetonate is coated on top of the substrate at $470^{\circ} \mathrm{C}$, followed by dipping the substrate in $\mathrm{TiCl}_{4}$ aqueous solution at $70^{\circ} \mathrm{C}$ for $30 \mathrm{~min}$, before heating the substrate in air at $500^{\circ} \mathrm{C}$. The deposition of $\mathrm{TiO}_{2}$ nanoparticles on the substrate can be done by spin coating method, followed by $30 \mathrm{~min}$ of heating in air at $500^{\circ} \mathrm{C}$. The next step is conducted under $\mathrm{N}_{2}$ atmosphere to prepare the perovskite layer. Mixture of $\mathrm{SnI}_{2} / \mathrm{PbI}_{2}$ and $\mathrm{CH}_{3} \mathrm{NH}_{3} \mathrm{I}$ (40 wt $\%, 1: 1 / \mathrm{mol}$ ) in DMF is spin coated and heated at $60^{\circ} \mathrm{C}$ for $30 \mathrm{~min}$ on a porous titania layer. Polymers are dissipated by spin coating on the substrate to employ the hole transporting layer P3HT. The flow diagram of the whole experiment procedure is shown in Fig. 3a (Ogomi et al., 2014; Bradley, 2015). Figure 3b shows the stability of this perovskite in the air with and without $\mathrm{PbI}_{2}$. Without $\mathrm{PbI}_{2}$, a rapid decrement in the $900 \mathrm{~nm}$ absorption in air can be observed. Eventually, the absorption drops from 1.0 to 0 in $60 \mathrm{~min}$. Meanwhile, when $\mathrm{PbI}_{2}$ is incorporated in the compound, the $900 \mathrm{~nm}$ absorption is relatively stable in air. The efficiency of this PSC is reported to be 14.4\% (Ogomi et al., 2014).
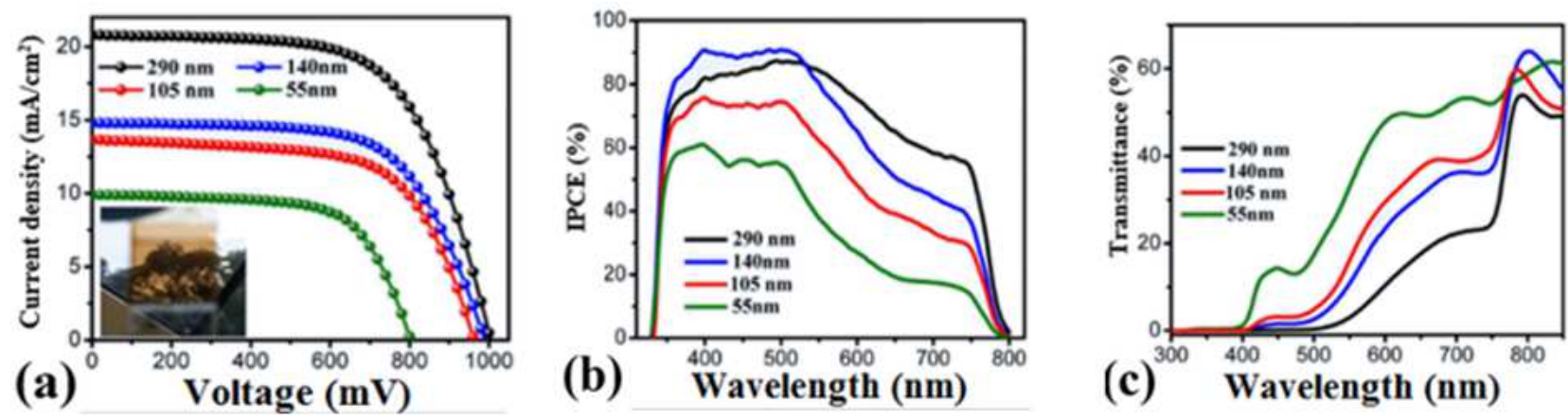

Fig. 2. (a) Current over voltage curves of PSC, with inset showing a photograph of a semitransparent PSC (b) IPCE and (c) transmittance spectra of complete PSCs with different CH3NH3PbI3 film thicknesses (Della Gaspera et al., 2015)
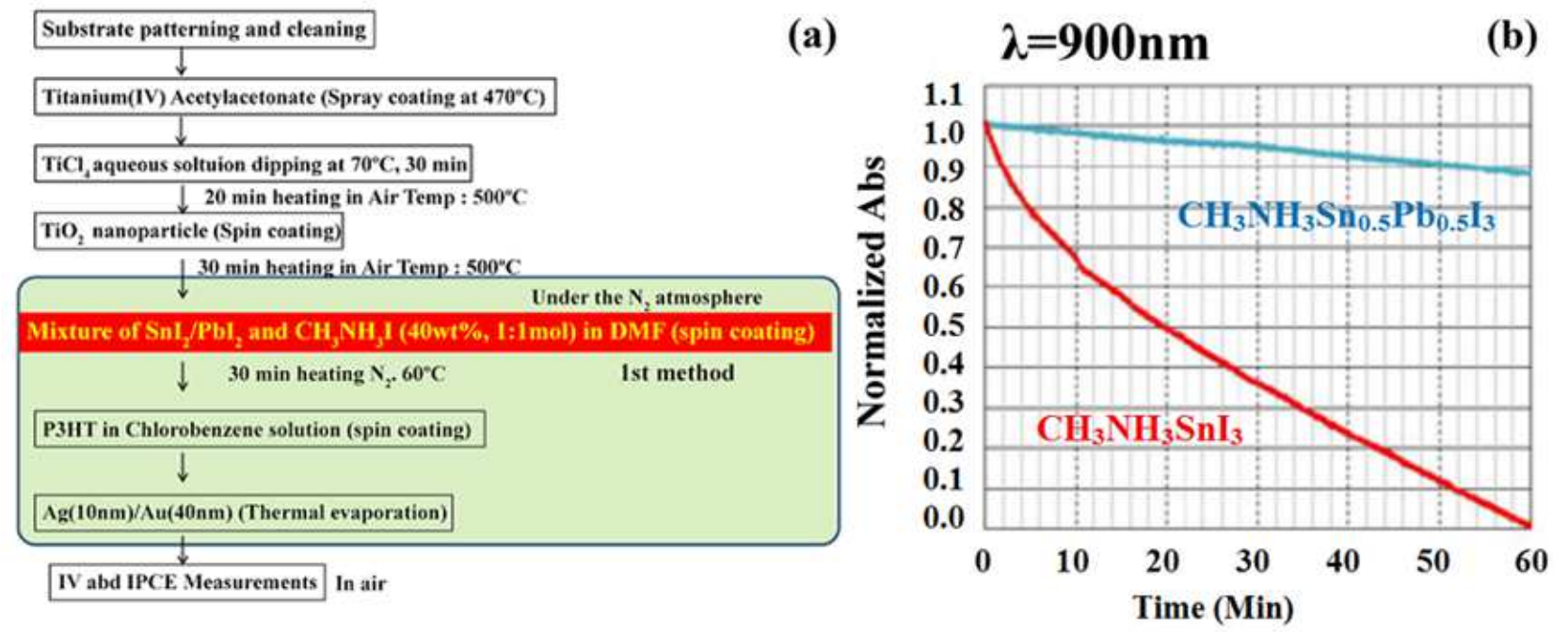

Fig. 3. (a) Preparation procedures of PSC under nitrogen gas condition (Ogomi et al., 2014) (b): Stability of PSC in air (Ogomi et al., 2014) 


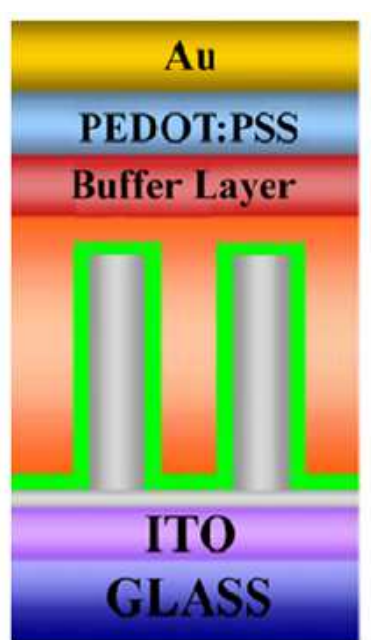

(a)

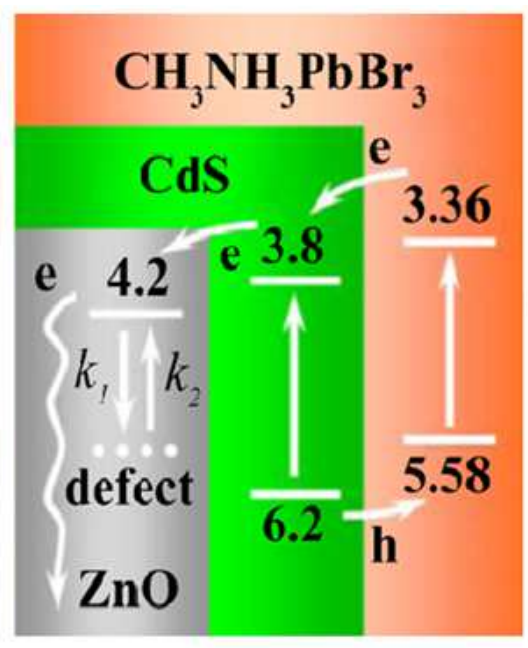

(c)

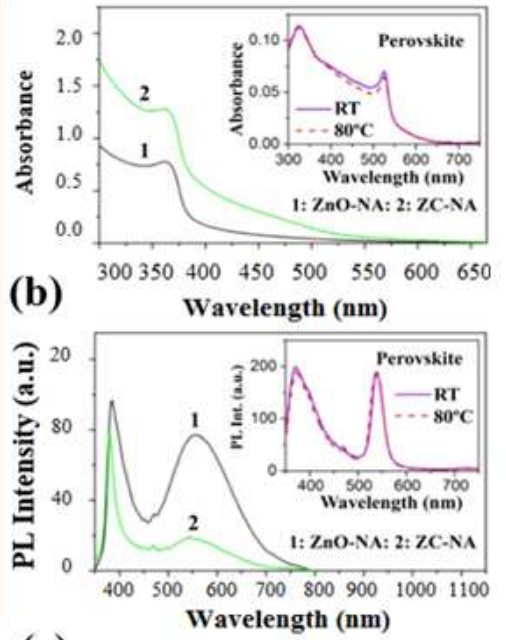

)

Fig. 4. (a): Structure of the device architecture (b): Absorption spectra (c): Room temperature PL (excited at $325 \mathrm{~nm}$ ) spectra of ZnO-NA and ZC-NA samples (Liu et al., 2015)

\section{Synthesis of $\mathrm{CH}_{3} \mathrm{NH}_{3} \mathrm{PbBr}_{3}$ (Bromine-based)}

The synthesis of $\mathrm{CH}_{3} \mathrm{NH}_{3} \mathrm{PbBr}_{3}$ starts by mixing $48 \mathrm{~mL}$ of methylamine with $57 \mathrm{~mL}$ of hydrobromic acid for $2 \mathrm{~h}$ with constant stirring. After that, by evaporating the solution for $1 \mathrm{~h}$ at $50^{\circ} \mathrm{C}$, the precipitate can be recovered. The arrows in Fig. 4a indicates the transfer of charge carriers, namely electrons and holes, inside the compound structure. The inset images in Fig. $4 \mathrm{~b}$ and $4 \mathrm{c}$ are showing the absorption and room temperature photoluminescence (excited at $325 \mathrm{~nm}$ ) spectra of the $\mathrm{CH}_{3} \mathrm{NH}_{3} \mathrm{PbBr}_{3}$ films with and without thermal annealing at $80^{\circ} \mathrm{C}$. The product of the chemical mixing is recrystallized by dipping into tetrahydrofuran twice and followed by drying process in vacuum oven at $60^{\circ} \mathrm{C}$ overnight. The dried $\mathrm{CH}_{3} \mathrm{NH}_{3} \mathrm{Br}$ is then mixed with $\mathrm{PbBr}_{2}$ in $\mathrm{N}, \mathrm{N}$-dimethylformamide with constant stirring for $12 \mathrm{~h}$ at $60^{\circ} \mathrm{C}$ to form the perovskite precursor (Liu et al., 2015).

\section{Synthesis of $\mathrm{K}_{2} \mathrm{La}_{2} \mathrm{Ti}_{3} \mathrm{O}_{10}$ Sensitizer}

PSC can be fabricated from other compound such as $\mathrm{K}_{2} \mathrm{La}_{2} \mathrm{Ti}_{3} \mathrm{O}_{10}$. It is prepared by conventional solid state reactions. First, stoichiometric amounts of $\mathrm{K}_{2} \mathrm{CO}_{3}$, $\mathrm{La}_{2} \mathrm{O}_{3}$ and $\mathrm{TiO}_{2}$ powders are mixed. In order to compensate the volatilization of the mixture, there is an excess amount of carbonate added. The mixture is calcinated in platinum crucible at $1000^{\circ} \mathrm{C}$ in air for $24 \mathrm{~h}$. In order to remove the excess alkali in the substance, the product is washed by distilled water and dried at $500^{\circ} \mathrm{C}$ to obtain anhydrous oxides. Next step is to protonate the surface. The powder form product is immersed in aqueous $\mathrm{HNO}_{3}$ solution at room temperature for $15 \mathrm{~h}$. Then, centrifuging process is carried out to obtain white precipitates. Later, the precipitate is immersed in aqueous ammonia solution for $15 \mathrm{~h}$ in nitrogen environment. Lastly, the precipitated powder is dried and annealed with the presence of nitrogen gas for $1 \mathrm{~h}$ at $400^{\circ} \mathrm{C}$. The end product is a light-yellowish powder. The absorbance and transmittance spectra of this type of PSC are shown in Fig. 5a and 5b (Huang et al., 2010).

\section{Synthesis of $\mathrm{La}_{0.7} \mathrm{Sr}_{0.3} \mathrm{MnO}_{3}$ Nano-Perovskite}

$\mathrm{La}_{0.7} \mathrm{Sr}_{0.3} \mathrm{MnO}_{3}$ is prepared using the citrate method. The chemicals used in the synthesis process are 0.0031 mol of $\mathrm{La}\left(\mathrm{NO}_{3}\right)_{3} \cdot 6 \mathrm{H}_{2} \mathrm{O}, 0.0043 \mathrm{~mol}$ of $\mathrm{Mn}\left(\mathrm{NO}_{3}\right)_{2} \cdot 4 \mathrm{H}_{2} \mathrm{O}$ and $0.0013 \mathrm{~mol}$ of $\mathrm{Sr}(\mathrm{NO} 3)_{2}$ precursors in the presence of $0.0205 \mathrm{~mol}$ of citric acid. All the chemicals with respective number of moles are added together and left to evaporate overnight at $60^{\circ} \mathrm{C}$. Then, the products are dried subsequently at $80^{\circ} \mathrm{C}$ and $150^{\circ} \mathrm{C}$ for $24 \mathrm{~h}$. To get the end product, the mixture is calcinated for $9 \mathrm{~h}$ at $900^{\circ} \mathrm{C}$. The resulting material is powdered. The absorbance of this type of PSC can be seen in Fig. 5c (Ghiasi and Malekzadeh, 2014).

\section{Synthesis of Hybrid PSC with Planar Heterojunction Structure (ITO/ZnO/CH $\mathrm{NH}_{3} \mathrm{PbI}_{3} /$ spiro-OMeTAD/Ag)}

An organic/inorganic hybrid solar cell is the combination of a mesoporous scaffold, an organic hole transporter and a perovskite light absorber. They have emerged at the forefront of solution process to enable the operation of photovoltaic devices. The sintering process for mesoporous metal-oxide support requires temperature up to $500^{\circ} \mathrm{C}$ for $8 \mathrm{~h}$. The hybrid PSC device architecture, photograph of a bending test on the hybrid PSC fabricated on a flexible PET substrate, J-V characteristic curve, IPCE spectrum and the efficiency curve of the hybrid PSC are shown in Fig. 6a-f. 

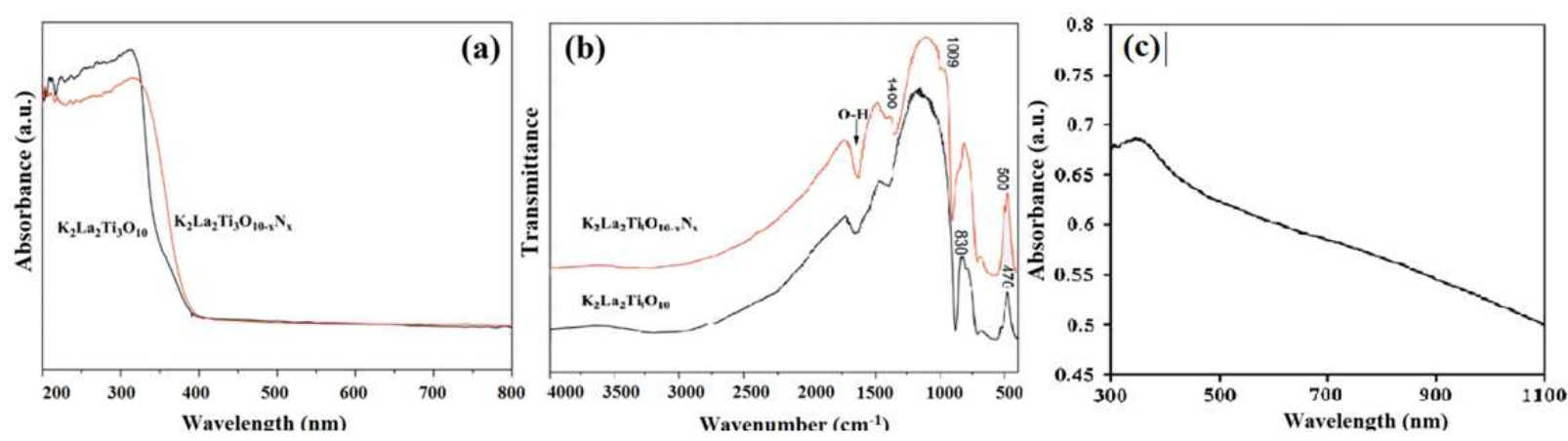

Fig. 5. (a) Absorbance spectra and (b): Transmittance spectra of $\mathrm{K}_{2} \mathrm{La}_{2} \mathrm{Ti}_{3} \mathrm{O}_{10}$ powder and nitrogen-doped $\mathrm{K}_{2} \mathrm{La}_{2} \mathrm{Ti}_{3} \mathrm{O}_{10-\mathrm{x}} \mathrm{N}_{\mathrm{x}}$ powder (Huang et al., 2010) (c): UV-Vis absorbance spectrum of $\mathrm{La}_{0.7} \mathrm{Sr}_{0.3} \mathrm{MnO}_{3}$ sample (Ghiasi and Malekzadeh, 2014)
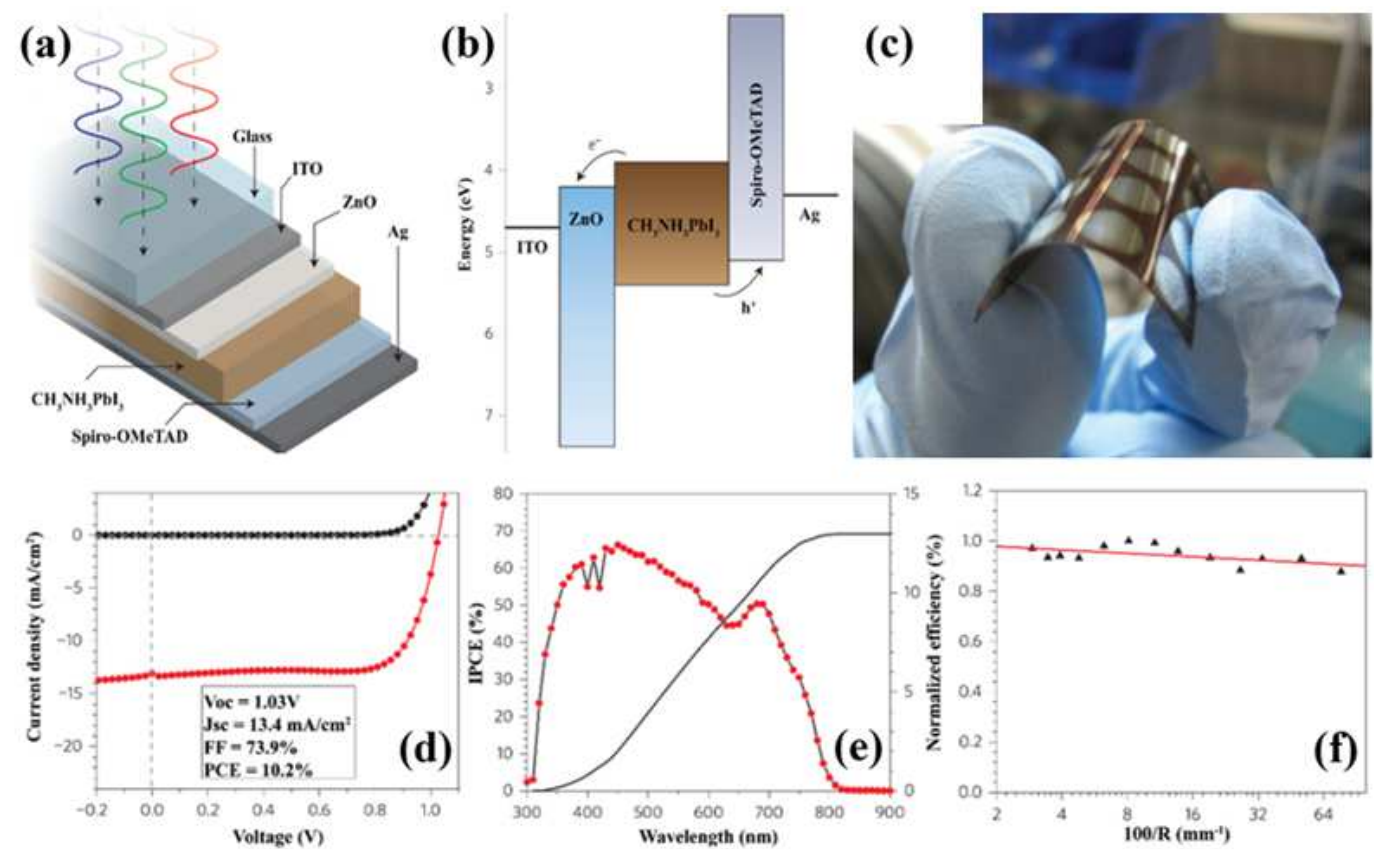

Fig. 6. (a) Device architecture of the ITO/ZnO/CH $\mathrm{NH}_{3} \mathrm{PbI}_{3} /$ spiro-OMeTAD/Ag cells (b) Energy levels (relative to vacuum) of the various device components (c) Photograph of device (d) J-V characteristic curve (e) IPCE spectrum (f) Normalized PCE (measured on a flat device) after first bending the substrate around a cylindrical object of the specified radius (R) (Liu and Kelly, 2014)

Thin film of $\mathrm{ZnO}$ nanoparticles can be used as an electron transport layer in $\mathrm{CH}_{3} \mathrm{NH}_{3} \mathrm{PbI}_{3}$ based solar cells. $\mathrm{ZnO}$ layer does not require sintering and it is thinner than $\mathrm{TiO}_{2}$. Based on these advantages a flexible solar cell with power efficiency of $10 \%$ can be fabricated. By using $\mathrm{ZnO}$ thin film, the performance of the solar cells prepared on rigid substrates is improved also. These cells can achieve a power conversion efficiencies as high as $15.7 \%$ under measurement of AM1.5 G illumination. First step is the synthesis of $\mathrm{ZnO}$ nanoparticles. $\mathrm{ZnO}$ nanoparticles are prepared using a precipitation method with zinc acetate as precursor material and $\mathrm{KOH}$ as precipitating agent. The $\mathrm{ZnO}$ nanoparticles solution is filtered by going through a $0.45 \mathrm{~mm}$ PVDF syringe filter. This solar is fabricated on ITO coated glass substrate that has the $20 \Omega \mathrm{sq}^{-1}$ sheet resistance. Then, a thin layer of $\mathrm{ZnO}$ nanoparticle is spin coated on the substrate at 3,000 RPM for $30 \mathrm{sec}$. Following that, a solution of $\mathrm{PbI}_{2}$ (dissolved in $\mathrm{N}, \mathrm{N}$-dimethylformamide with concentration of $460 \mathrm{mg} \mathrm{mL}^{-1}$ ) is spin coated on the top of the $\mathrm{ZnO}$ layer at 3,000 RPM for $15 \mathrm{sec}$. After several minutes of drying in the air, the substrate is dipped into $10 \mathrm{mg} \mathrm{mL}^{-1}$ solution of $\mathrm{CH}_{3} \mathrm{NH}_{3} \mathrm{I}$ for $40 \mathrm{sec}$ before being dried under a flow of clean air. The spiroOMeTAD base hole transfer layer $(80 \mathrm{mg}$ spiroOMeTAD, $28.5 \mathrm{~mL}$ 4-tertbutylpyridine and $17.5 \mathrm{~mL}$ lithium-bis(trifluoromethanesulfonyl)imide (Li-TFSI) solution $(520 \mathrm{mg}$ Li-TFSI in $1 \mathrm{~mL}$ acetonitrile) all dissolved in $1 \mathrm{~mL}$ chlorobenzene) is deposited by 4,000 RPM for $30 \mathrm{sec}$. Finally, at base pressure of $2 \times 10^{-6}$ 
mbar, a $150 \mathrm{~nm}$-thick silver layer is deposited by thermal evaporation. All the fabrication steps are carried out under ambient conditions.

The photovoltaic parameter graphs of this type of PSC are shown in Fig. 6. Figure 6d shows the J-V characteristic curve measurements of the highestperforming ITO/ZnO/CH $\mathrm{CH}_{3} \mathrm{NH}_{3} \mathrm{PbI}_{3}$ spiro-OMeTAD/Ag flexible device under $100 \mathrm{mWcm}^{-2}$ AM1.5G illumination and in the dark. Figure 6e represents the IPCE spectrum of the highest-performing ITO/ZnO/ $\mathrm{CH}_{3} \mathrm{NH}_{3} \mathrm{PbI}_{3}$ /spiro-OMeTAD/Ag flexible device. The integrated product of the IPCE spectrum with the AM1.5G photon flux is also shown (black line). All measurements in Fig. 6d-f were performed on a single device and were performed from the highest radius of curvature to the lowest (Liu and Kelly, 2014).

\section{Synthesis of Inorganic-Organic Hybrid PSC}

The fabrication methodology for a bilayer architecture has the key features of full solution-based processes to synthesize mesoscopic and planar structures. In the fabrication process, poly(triarylamine) acts as the HTM layer and $\mathrm{CH}_{3} \mathrm{NH}_{3} \mathrm{~Pb}\left(\mathrm{I}_{1-\mathrm{x}} \mathrm{Br}_{\mathrm{x}}\right)_{3}, \mathrm{x}=0.1-0.15$ acts as the absorber layer. First, with the spray pyrolysis method a thick layer of $\mathrm{TiO}_{2}(70 \mathrm{~nm})$ is deposited on top of a F-doped $\mathrm{SnO}_{2}$ (FTO, Pilkington, TEC8) substrate. In order to avoid direct contact between hole conducting layer and the FTO, a $20 \mathrm{mM}$ titanium diisopropoxide bis(acetylacetonate) solution is used at $450^{\circ} \mathrm{C}$. Next, a 200-300 nm thick mesoporous $\mathrm{TiO}_{2}$ film is spin coated on top of the bl$\mathrm{TiO}_{2} /$ FTO substrate. Then, in order for the organic components to be removed, the film is calcinated at $500^{\circ} \mathrm{C}$ for $1 \mathrm{~h}$ in air. After that, $27.86 \mathrm{~mL}$ of $\mathrm{CH}_{3} \mathrm{NH}_{2}(40 \%$ in

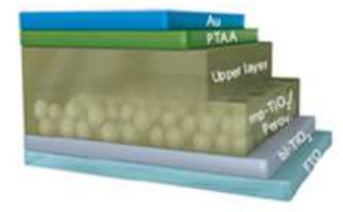

(a)
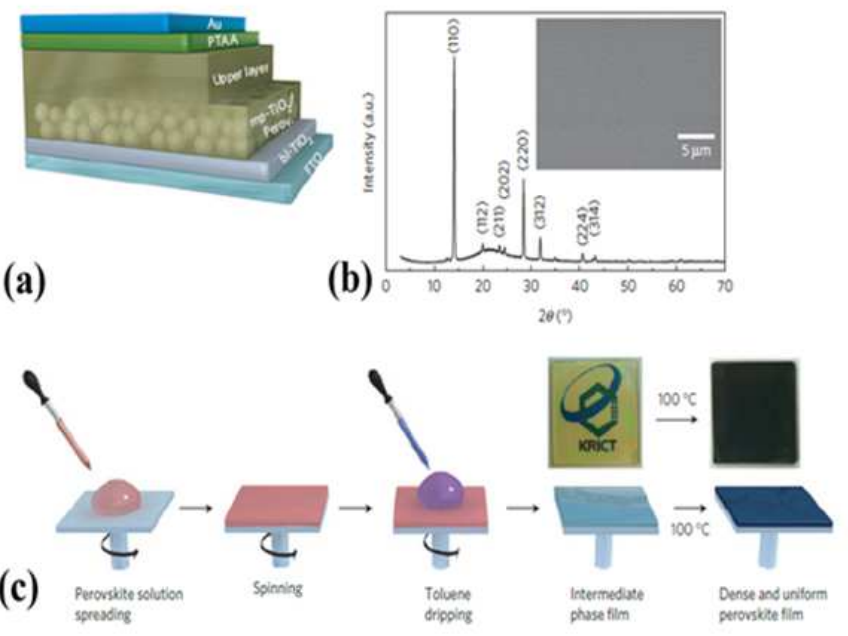

methanol) and $30 \mathrm{~mL}$ of $\mathrm{HI}$ ( $57 \mathrm{wt} \%$ in water) or $44 \mathrm{~mL}$ $\mathrm{HBr}(48 \mathrm{wt} \%$ in water are mixed in a $250 \mathrm{~mL}$ round-bottom flask at $0^{\circ} \mathrm{C}$ for $4 \mathrm{~h}$ with continuous stirring. By evaporation at $55^{\circ} \mathrm{C}$ for 1 hour, the precipitate is recovered. MAI and $\mathrm{MABr}$ are dissolved in ethanol before being recrystallized from diethyl ether and dried at $60^{\circ} \mathrm{C}$ in a vacuum oven for $24 \mathrm{~h}$. The prepared powders of $\mathrm{PbI}_{2}$ and $\mathrm{PbBr}_{2}$ for $0.8 \mathrm{M}$ $\mathrm{MAPb}\left(\mathrm{I}_{1-\mathrm{x}} \mathrm{Br}_{\mathrm{x}}\right)_{3}(\mathrm{x}=0.1-0.15)$ solution are stirred in a mixture of GBL and DMSO $(7: 3 \mathrm{v} / \mathrm{v})$ at $60^{\circ} \mathrm{C}$ for $12 \mathrm{~h}$. Using a continuous two-step spin coating process at 1,000 and 5,000 RPM for 10 and $20 \mathrm{sec}$ respectively, the resulting solution is coated on top of the $\mathrm{mp}-\mathrm{TiO}_{2} / \mathrm{bl}-\mathrm{TiO}_{2} / \mathrm{FTO}$ substrate. In the second spin coating step, the substrate is treated with toluene drop casting (around $1 \times 1 \mathrm{~cm}$ ). A solution of poly (triarylamine) (15 mg, PTAA, EM Index, $\left.\mathrm{M}_{\mathrm{w}}=17,500 \mathrm{gmol}^{-1}\right)$ in toluene $(1.5 \mathrm{~mL})$ is mixed with 15 $\mu \mathrm{L}$ of a solution of lithium bistrifluoromethanesulphonimidate $(170 \mathrm{mg})$ in acetonitrile $(1 \mathrm{~mL})$ and $7.5 \mu \mathrm{L}$ 4-tert-butylpyridine and spin-coated on the $\mathrm{MAPb}\left(\mathrm{I}_{1-\mathrm{x}} \mathrm{Br}_{\mathrm{x}}\right)_{3}(\mathrm{x}=0.1-0.15) / \mathrm{mp}-\mathrm{TiO}_{2} / \mathrm{bl}_{-} \mathrm{TiO}_{2} / \mathrm{FTO}$ substrate at 3,000 RPM for $30 \mathrm{sec}$. Finally, an Au counterelectrode is deposited by thermal evaporation. The active area of this electrode is fixed at $0.16 \mathrm{~cm}^{2}$.

The photovoltaic parameter result of this PSC is shown in Fig. 7 and Table 1. The $\mathrm{J}_{\mathrm{SC}}, \mathrm{V}_{\mathrm{OC}}$ and $\mathrm{FF}$ values obtained from the I-V curve of the reverse scan are $19.2 \mathrm{mAcm}^{-2}$, $1.09 \mathrm{~V}$ and 0.69 respectively, yielding a PCE of $14.4 \%$ under standard AM 1.5 conditions. In contrast, the corresponding values from the I-V curve of the forward scan are $19.2 \mathrm{mAcm}^{-2}, 1.07 \mathrm{~V}$ and 0.44 respectively, showing a pronounced discrepancy of $9.1 \%$ in overall efficiency. Certified power conversion efficiency up to $16.2 \%$ is achieved in this PSC (Jeon et al., 2014).
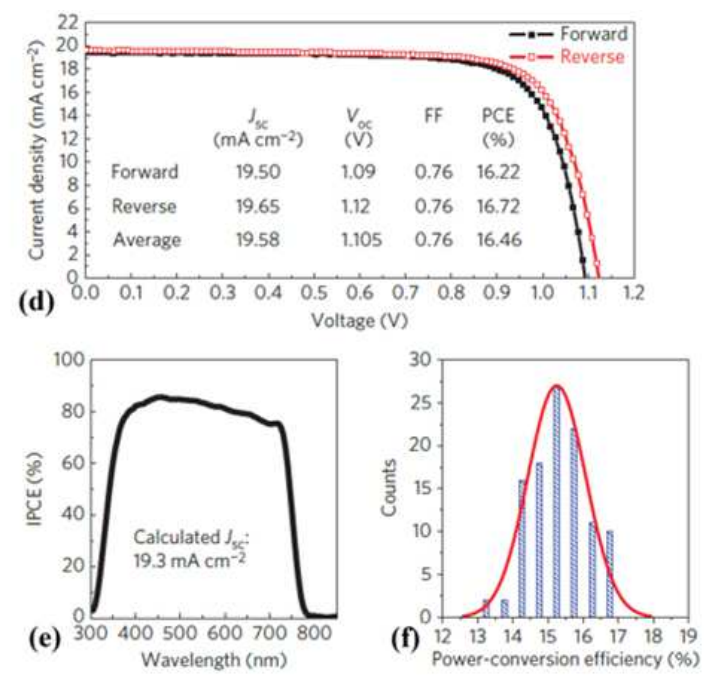

Fig. 7. (a) Device architecture of the bilayered perovskite solar cell (glass/FTO/bl- $\mathrm{TiO}_{2} / \mathrm{mp}-\mathrm{TiO}_{2}$-perovskite nanocomposite layer/perovskite upper layer/PTAA/Au) (b) XRD pattern of the annealed perovskite coated on fused silica substrate. The inset shows a SEM image of a surface consisting of a glass $/ \mathrm{FTO} / \mathrm{bl}-\mathrm{TiO}_{2} / \mathrm{mp}-\mathrm{TiO}_{2}$-perovskite nanocomposite layer/perovskite upper layer (c) Solvent engineering procedure for preparing the uniform and dense perovskite film (d) J-V curves measured by forward and reverse scans, fabricated using a $200 \mathrm{~nm}$-thick mp- $\mathrm{TiO}_{2}$ layer (e) The IPCE spectrum for the best cell (f) Histogram of average efficiencies for 108 devices (Jeon et al., 2014) 
Table 1. Photovoltaic performance of perovskite solar cells without mp- $\mathrm{TiO}_{2}$ or with 200-nm-thick mp- $\mathrm{TiO}_{2}$ (Jeon et al., 2014)

\begin{tabular}{llllll}
\hline Device & Scan direction & $\mathrm{J}_{\mathrm{SC}}\left(\mathrm{mA} / \mathrm{cm}^{2}\right)$ & $\mathrm{V}_{\mathrm{OC}}(\mathrm{V})$ & $\mathrm{FF}$ & PCE $(\%)$ \\
\hline $\mathrm{W} / \mathrm{O} \mathrm{mp}-\mathrm{TiO}_{2}$ & Forward & 19.2 & 1.07 & 0.44 & 9.1 \\
& Reverse & 19.2 & 1.09 & 0.69 & 14.4 \\
200-nm-thick mp- $\mathrm{TiO}_{2}$ & Forward & 20.1 & 1.08 & 0.73 & 15.8 \\
& Reverse & 19.9 & 1.06 & 0.75 & 15.9 \\
\hline
\end{tabular}

Table 2. Different fabrication methods of HTM layer

\begin{tabular}{|c|c|c|}
\hline HTM & Fabrication methods & References \\
\hline \multirow[t]{5}{*}{ Spiro-OTAD } & $\begin{array}{l}\text { Dissolve spiro-MeOTAD in chorobenzene. Obtain } 10 \% \text { of (mole/mole) } \\
\text { p-type doping of HTM by adding tris(2-(1H-pyrazol-1-yl)-4-tert } \\
\text { butylpyrydine) cobalt(III) bis(trifluoromethylsulphonyl)imide (FK209) } \\
\text { into the solution. Spin coat on top of substrate. }\end{array}$ & Ramos et al. (2014) \\
\hline & $\begin{array}{l}\text { Add } 1 \mathrm{~mL} \text { of chlorobenzene with } 0.70 \mathrm{M} \text { solution of Spiro-MeOtad with } \\
\mathrm{Li} \text {-TFSI and t-BP as additives. Spin coat on top of substrate with speed of } \\
2000 \mathrm{rpm} \text { for } 30 \mathrm{~s} \text {. Store the device in the dark condition for overnight to } \\
\text { dry the layer. To complete the fabrication of solar cell, gold electrodes } \\
\text { will be deposited by thermal evaporation with thickness of } 100 \mathrm{~nm} \text {. }\end{array}$ & Sheikh et al. (2015) \\
\hline & $\begin{array}{l}\text { The solution can be prepared under N2 condition. Mix } 10 \text { wt. } \% \text { of Co(III) } \\
\text { complex (FK-102) in a solution of Spiro-MeOTAD }(2,20,7,70 \text {-tetrakis } \\
\text { (N, N-di-p-methoxyphenylamine)- } 9,90 \text {-spiro bifluorene in chlorobenzene } \\
\left(120 \mathrm{mg} \mathrm{mL} \mathrm{m}^{-1}\right) \text {. Add } 24 \mu \mathrm{L} \text { of lithium bis(trifluoromethanesulfonyl)imide } \\
\text { dissolved in acetonitrile }\left(520 \mathrm{mg} \mathrm{mL}^{-1}\right) \text { and } 37 \mu \mathrm{L} \text { of ter-butylpyridin. Spin } \\
\text { coat the solution on the perovskite layer for } 30 \mathrm{~s} \text { with speed of } 4000 \mathrm{rpm} \text {. }\end{array}$ & Li et al. (2015) \\
\hline & $2,2^{\prime}, 7,7^{\prime}$-tetrakis-(N, N-dipmethoxyphenylamine) 9,90-spirobifluorene & Zhang et al. (2015) \\
\hline & $\begin{array}{l}\text { (Spiro-MeOTAD) will spin coated on top of substrate with } 2000 \mathrm{rpm} \text { for } \\
60 \text { s under ambient condition. Leave the device in a closed box with silica } \\
\text { desiccant for overnight in air. }\end{array}$ & Di Giacomo et al. (2014) \\
\hline \multirow[t]{2}{*}{ Polymer } & $\begin{array}{l}\text { Use P3HT and copolymer P. Spin coat the HTMs polymer using HTMs } \\
\text { solution in chlorobenzene on top of substrate with speed of } 2500 \text { RPM for } \\
30 \text { sec. Leave the device to dry for } 1 \mathrm{~h} \text {. }\end{array}$ & Nagarjuna et al. (2015) \\
\hline & $\begin{array}{l}\text { Mix P3HT solution with dichlorobenzene }\left(10 \mathrm{mg} \mathrm{mL}^{-1}\right) \text {. Spin coat the } \\
\text { solution on the substrate at } 1500 \mathrm{rpm} \text { for } 60 \mathrm{sec} \text {. On top of the HTM layer } \\
\text { through shadow mask deposit a gold anode with the thickness of } 220 \mathrm{~nm} \text {. }\end{array}$ & Zhang et al. (2015) \\
\hline
\end{tabular}

\section{Synthesis of HTM}

The type of layers on top of the substrates, namely the Electron Transport Layer (ETL) and Hole Transporting Layer (HTL), is an important consideration in the fabrication of solar cell. These layers will facilitate the movement of holes and electrons around the device, thus a good choice in the fabrication of these layers will increase the efficiency of the PSC. From Table 2, one can observe that most of the fabrication methods of HTM layers are almost similar. Besides that, this table is useful to find the suitable method for the fabrication of HTM layer (either polymer or spiro-OTAD).

\section{Summary of Fabrication Methods}

Fabrication plays an important role in development of PSC and The summary of fabrication methods and chemicals are shown in Table 3. Based on Table 3, one can deduce that spin coating plays a major role in the fabrication of PSC.

\section{Impact of Various Factors on PSC Performance}

Despite the high efficiency of PSC, it still faces several challenges such as instability and some other issues, thus researches are going on to explore the effect of those issues on the performance of PSC. In this section, a review on the different impacts of various factors such as atmosphere condition, film thickness and properties, HTM, electron transport, external electric field, blocking layer, transport layer, $\mathrm{CBO}$ and VBO absorber layer, heat treated ion assisted film, thermal annealed effect, reduced graphene oxide, blade coating and low temperature solution on the performance of PSC.

\section{Impact of Storage Conditions on PSC Performance}

In this section, the impact of varying storage conditions on the photovoltaic performance of $\mathrm{TiO}_{2}$ $\mathrm{CH}_{3} \mathrm{NH}_{3} \mathrm{PbI}_{3 \mathrm{x}} \mathrm{Cl}_{\mathrm{x}}$ spiro-OMeTAD solar cells will be analyzed. The results of the PSC performance under different dark storage conditions are summarized in Table 4. Based on the results shown in Table 4, it is apparent that the dry air is the most affordable storage condition to accomplish high energy conversion efficiency during the first few hours. Precursor composition, perovskite morphology, pore filling and processing temperature are significant factors in evaluating the solar cell efficiency. During the initial couple of hours, dry air is the most suitable storage condition for high energy conversion 
efficiency. Ambient atmospheric condition, proper oxidization and p-doping spiro-OMeTAD are important elements that need to be considered during the drying process as it is tightly related to efficiency. To achieve efficiency of $15 \%, \mathrm{TiO}_{2}$ and spiro-bi fluorine have to be used as the electron collector and hole conductor respectively. Absence of oxygen during the drying process can lead to decrement and increment in the electron conductivity and the recombination of charge carrier respectively. Electron conductivity of the LiTFSI-doped spiro-OMeTAD increases by two orders of magnitude when it is exposed to dry air. Some of the other factors that have been improved relatively to dry $\mathrm{N}_{2}$ and vacuum conditions are photo-current density, FF and PCE.

Table 3. Summary of fabrication methods of PSC

\begin{tabular}{|c|c|c|c|c|c|}
\hline \multirow[b]{2}{*}{ PSC } & \multicolumn{5}{|l|}{ Fabrication techniques } \\
\hline & Dipping & Spin coating & Spray pyrolysis & Thermal evaporation & References \\
\hline $\begin{array}{l}\mathrm{CH}_{3} \mathrm{NH}_{3} \mathrm{PbI}_{(3-\mathrm{x})} \\
/ \mathrm{P} 3 \mathrm{HT} / \mathrm{Ag} / \mathrm{Au}\end{array}$ & $\begin{array}{l}\mathrm{TiCl}_{4} \text { aqueous solution } \\
\text { at } 70^{\circ} \mathrm{C} \text { for } 30 \mathrm{~min}\end{array}$ & $\begin{array}{l}\mathrm{TiO}_{2} \text { nanoparticles, } \mathrm{P} 3 \mathrm{HT} \\
\text { in chlorobenzene solution }\end{array}$ & At $470^{\circ} \mathrm{C}$ & $\operatorname{Ag}(10 \mathrm{~nm}) / \mathrm{Au}(40 \mathrm{~nm})$ & Ogomi et al. (2014) \\
\hline $\mathrm{CH}_{3} \mathrm{NH}_{3} \mathrm{PbI}_{3-\mathrm{x}} \mathrm{Cl}_{\mathrm{x}}$ & - & $\begin{array}{l}\mathrm{TiO}_{2}(2000 \mathrm{RPM}, 60 \mathrm{~s}) \\
\text { Dimethylformamide (DMF) } \\
\text { solution }(2000 \mathrm{rpm}, 60 \mathrm{~s})\end{array}$ & - & - & $\begin{array}{l}\text { Wang et al. ( } 2015 \text {; } \\
\text { Sheikh et al., 2015; } \\
\text { Di Giacomo et al., } \\
\text { 2014) }\end{array}$ \\
\hline $\mathrm{CH}_{3} \mathrm{NH}_{3} \mathrm{I}$ & - & $\begin{array}{l}\text { Dyesol paste (5000 RPM, } \\
30 \mathrm{~s})\end{array}$ & $\begin{array}{l}\text { Titanium diisopropoxie } \\
\text { bis(acetyl acetonate) } \\
\text { at } 450^{\circ} \mathrm{C}\end{array}$ & - & Ramos et al. (2014) \\
\hline $\mathrm{CH}_{3} \mathrm{NH}_{3} \mathrm{PbI}_{3}$ & - & $\begin{array}{l}\mathrm{CH}_{3} \mathrm{NH}_{3} \mathrm{PbI}_{3}, \mathrm{PbI}_{2} \text { in } \mathrm{N}, \\
\text { Ndimethylformamide } \\
\text { in } 70^{\circ} \mathrm{C}\end{array}$ & $\begin{array}{l}\mathrm{TiO}_{2} \text { deposited on } \\
\text { the FTO glass }\end{array}$ & - & $\begin{array}{l}\text { Xin et al. }(2014 \text {; } \\
\text { Woojun et al., } \\
\text { 2014) }\end{array}$ \\
\hline $\mathrm{CH}_{3} \mathrm{NH}_{3} \mathrm{PbI}_{3} / \mathrm{C}_{4} \mathrm{H}_{6} \mathrm{O}_{2}$ & - & $\begin{array}{l}30 \mathrm{mM} \text { tetrabutyl titanate } \\
\text { in isopropyl alcohol } \\
\text { (500 RPM, } 15 \mathrm{~s})\end{array}$ & - & - & Xiao et al. (2014) \\
\hline $\mathrm{PbI}_{2}+\mathrm{CH}_{3} \mathrm{NH}_{3}$ & $\begin{array}{l}\mathrm{CH}_{3} \mathrm{NH}_{3} \mathrm{I} \text { in anhydrous } \\
\text { isopropanol } 10 \mathrm{mg} \mathrm{mL}^{-1}\end{array}$ & $\begin{array}{l}\mathrm{PbI}_{2} \text { in } \mathrm{N} \text {, } \\
\text { Ndimethylformamide, } \\
460 \mathrm{mg} \mathrm{mL} 1 \text { heated at } 60^{\circ} \mathrm{C} \\
(3000 \mathrm{rpm}, 40 \mathrm{~s})\end{array}$ & compact $\mathrm{TiO}_{2}$ & - & Razza et al. (2015) \\
\hline $\begin{array}{l}\mathrm{K}_{2} \mathrm{La}_{2} \mathrm{Ti}_{3} \mathrm{O}_{10} \\
\text { doped by aqueous } \\
\mathrm{NH}_{3} \text { solution }\end{array}$ & - & - & - & - & Huang et al. (2010) \\
\hline $\begin{array}{l}\mathrm{CH}_{3} \mathrm{NH}_{3} \mathrm{PbI}_{3}-\mathrm{TiO}_{2} \\
\mathrm{NCS}\end{array}$ & $8 \mathrm{mg} \mathrm{mL}^{-1} \mathrm{CH}_{3} \mathrm{NH}_{3} \mathrm{I}$ & $\begin{array}{l}0.554 \mathrm{~g} \mathrm{~mL}^{-1} \mathrm{PbI}_{2} \text { in } \mathrm{N}, \\
\mathrm{N} \text {-dimethylformamide } \\
\text { (DMF) }\end{array}$ & & & Zhong et al. (2015) \\
\hline $\mathrm{CH}_{3} \mathrm{NH}_{3} \mathrm{~Pb}_{\mathrm{X} 3}$ & $\begin{array}{l}0.04 \mathrm{M} \mathrm{TiCl}_{4} \text { in } \\
\mathrm{H}_{2} \mathrm{O} \text { for } 30 \mathrm{~min}\end{array}$ & mesoporous $\mathrm{TiO}_{2}$ layer & thin layer of $\mathrm{TiO}_{2}$ & $\begin{array}{l}\text { Deposition of } 80 \\
\mathrm{~nm} \text { thick gold }\end{array}$ & Sfyri et al. (2015) \\
\hline $\begin{array}{l}\text { PZT-Terray } \\
\text { Perovskites }\end{array}$ & - & - & - & - & Wasa et al. (2016) \\
\hline $\mathrm{MoO}_{3}-\mathrm{Au}-\mathrm{MoO}_{3}$ & - & $\begin{array}{l}\text { 1:1 } \mathrm{M} \text { ratio of } \mathrm{CH}_{3} \mathrm{NH}_{3} \mathrm{I} \\
\text { and } \mathrm{PbI}_{2} \text { Spiro-OMeTAD } \\
(3000 \mathrm{rpm}, 30 \mathrm{~s})\end{array}$ & - & $\begin{array}{l}\text { Dissolving } 41.6 \mathrm{mg} \\
\text { Spiro-OMeTAD, } \\
7.5 \mu \mathrm{L} \text { of a stock } \\
\text { solution of } 520 \mathrm{mg} \mathrm{mL}^{-1} \\
\text { LiTFSi in acetonitrile } \\
\text { and } 16.9 \mu \mathrm{L} \text { TBP in } \\
0.5 \mathrm{~mL} \text { chlorobenzene }\end{array}$ & $\begin{array}{l}\text { Della Gaspera et al. } \\
\text { (2015) }\end{array}$ \\
\hline 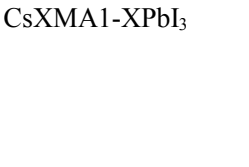 & - & $\begin{array}{l}\text { Equimolar amounts of } \\
\text { CsI: } \mathrm{CH}_{3} \mathrm{NH}_{3} \mathrm{I} \text { and } \mathrm{PbI}_{2} \text { in } \\
\text { a mixed solvent consisting } \\
\text { of } 120 \mathrm{mg} \mathrm{mL} \mathrm{m}^{-1} \mathrm{DMF}: \mathrm{GBL} \\
(97: 3[\mathrm{vol} \%])\end{array}$ & - & - & Choi et al. (2014) \\
\hline $\begin{array}{l}\mathrm{CH}_{3} \mathrm{NH}_{3} \mathrm{PbI}_{3}-\mathrm{xClx} \\
\left(=\mathrm{MAPbI}_{3-\mathrm{x}} \mathrm{Cl}_{\mathrm{x}}\right)\end{array}$ & - & $\begin{array}{l}\mathrm{TiO}_{2} \text { films at } 2500 \mathrm{RPM} \\
\text { for } 30 \mathrm{~s} \text {, in argon-filled } \\
\text { glove box }\end{array}$ & - & - & $\begin{array}{l}\text { Li et al. }(2015 ; \\
\text { Zhang et al., 2015) }\end{array}$ \\
\hline $\begin{array}{l}\mathrm{Zo-PET} \text { and } \\
\mathrm{CH}_{3} \mathrm{NH}_{3} \mathrm{PbI}_{3}\end{array}$ & - & $\begin{array}{l}\text { Titania suspension onto } \\
\text { IZO-PET at } 2000 \mathrm{rpm} \\
\text { for } 60 \mathrm{~s}\end{array}$ & - & - & $\begin{array}{l}\text { Dkhissi et al. } \\
\text { (2015) }\end{array}$ \\
\hline
\end{tabular}

Table 4. Photovoltaic parameters of the solar cells stored under disparate environmental conditions (Sheikh et al., 2015)

\begin{tabular}{llrr}
\hline Dark storage condition & $\mathrm{J}_{\mathrm{SC}}\left(\mathrm{mA} / \mathrm{cm}^{2}\right)$ & $\mathrm{V}_{\mathrm{OC}}(\mathrm{V})$ & $\mathrm{FF}(\%)$ \\
\hline Vacuum & 12.2 & 0.77 & 57.5 \\
Dry air & 18.4 & 0.89 & 5.4 \\
Dry nitrogen & 13.4 & 0.80 & 68.9 \\
\hline
\end{tabular}


(a)

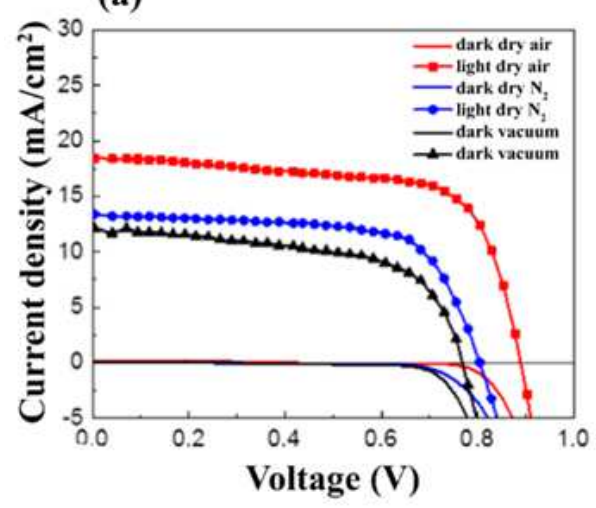

(b)

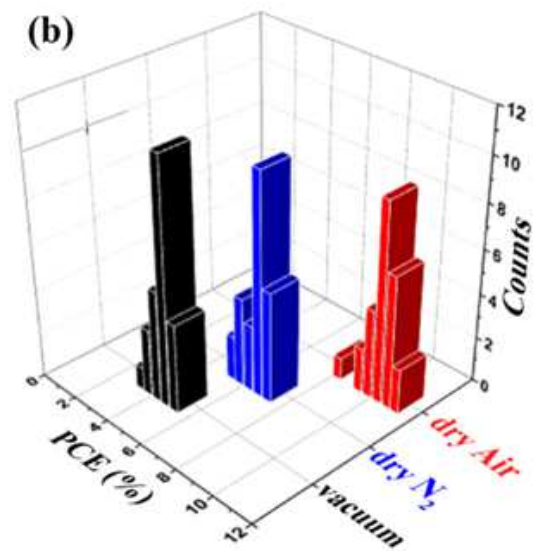

Fig. 8. (a) J-V characteristic curve and (b) Histograms of the PCE (\%) data for the treated PSCs (24 samples for each of the three sets) (Sheikh et al., 2015)

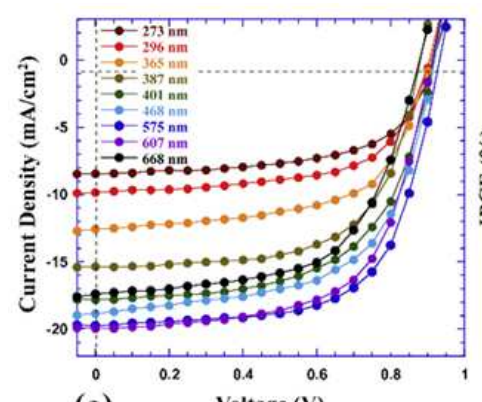

(a)

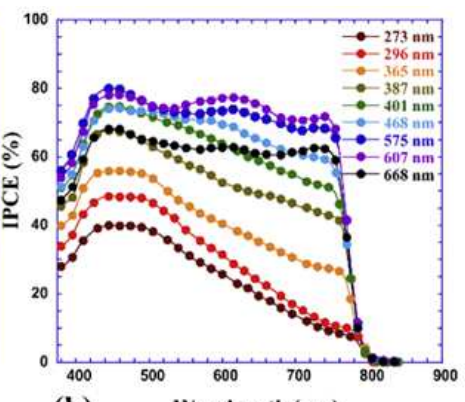

(b)

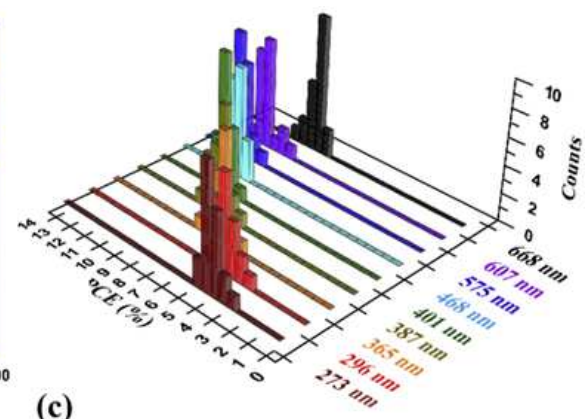

(c)

Fig. 9. (a) J-V characteristics of PHJ perovskites hybrid PSC with disparate thickness layer of $\mathrm{CH}_{3} \mathrm{NH}_{3} \mathrm{PbI}_{3-\mathrm{x}} \mathrm{Cl}_{\mathrm{x}}$ (b) IPCE spectra of pero-HSCs (c) Comparison of histograms of efficiencies of pero-HSCs perovskites with varying film thickness (Wang et al., 2015)

The performance graphs of three solar cells treated under different dark storage conditions are shown in Fig. 8. The charge carrier density is enhanced with high resistivity and $\mathrm{p}$ doping. As mentioned before, long term stability is a big issue in PSC and this concern can only be minimized by keeping the device away from detrimental moisture and by encapsulation process after proper oxidation of HTM. Fermi level of the spiroOMeTAD becomes lower due to the light illumination and this will result in higher $\mathrm{V}_{\mathrm{OC}}$. The highest efficiency of $11.2 \%$ is achieved under dry air condition, whereas the efficiency is only 5.4 and $7.2 \%$ under vacuum and dry $\mathrm{N}_{2}$ conditions respectively. Furthermore, PSC stored under dry air condition has the highest open circuit voltage of $0.89 \mathrm{~V}$, highest photo-current density of 18.4 $\mathrm{mA} / \mathrm{cm}^{2}$ and largest fill factor of $68.9 \%$. Although the PSC stored in dry air exhibits a marginally better performance than PSCs stored under dry $\mathrm{N}_{2}$ and vacuum conditions, the atmospheric gas storage condition does not have much effect on the final efficiency. Besides, the light harvesting efficiency remains generally the same under different storage conditions (Sheikh et al., 2015).

\section{Impact of Film Thickness on PSC Performance}

Even though a considerable amount of literature on the on performance of perovskite has been published, the correlation between the film thickness of $\mathrm{CH}_{3} \mathrm{NH}_{3} \mathrm{PbI}_{3}$ ${ }_{\mathrm{x}} \mathrm{Cl}_{\mathrm{x}}$ (hybrid) perovskite layers and its performance are rarely addressed. As shown in Fig. $9 \mathrm{a}$ and $9 \mathrm{~b}$, the effects of $\mathrm{CH}_{3} \mathrm{NH}_{3} \mathrm{PbI}_{3-\mathrm{x}} \mathrm{Cl}_{\mathrm{x}}$ film thickness on both $\mathrm{J}_{\mathrm{SC}}$ and PCE are moderate when the thickness of $\mathrm{CH}_{3} \mathrm{NH}_{3} \mathrm{PbI}_{3-\mathrm{x}} \mathrm{Cl}_{\mathrm{x}}$ film is larger than $400 \mathrm{~nm}$. When the film thickness is decreased to around $200 \mathrm{~nm}$, both $\mathrm{J}_{\mathrm{SC}}$ and PCE are improved by 15 and $37 \%$, respectively. Photo-responses below $500 \mathrm{~nm}$ are moderately enhanced in comparison with photo-responses in the wavelength region from 550 to $800 \mathrm{~nm}$, which are dramatically enhanced. Minimization of the surface charge carrier recombination due to the enlarged surface coverage leads to the reduction of energy loss. Efficiencies of PHJ peroHSCs are heavily depending on the film morphology of $\mathrm{CH}_{3} \mathrm{NH}_{3} \mathrm{PbI}_{3-\mathrm{x}} \mathrm{Cl}_{\mathrm{x}}$ layer when the film thickness is larger than $400 \mathrm{~nm}$. Based on Table 5, due to the large surface roughness in the films thicker than $600 \mathrm{~nm}$, both $\mathrm{J}_{\mathrm{SC}}$ and PCEs will decrease. From Table 5, the relationship 
between the efficiencies of "planar heterojunction" and the thin film thicknesses, as well as the morphologies of solution-processed $\mathrm{CH}_{3} \mathrm{NH}_{3} \mathrm{PbI}_{3-\mathrm{x}} \mathrm{Cl}_{\mathrm{x}}$ perovskite layers can be observed (Wang et al., 2015).

In Table 6, the performance results are based on $\mathrm{TiO}_{2}$ thin films with different film thickness for quantum dot sensitized PSCs. As long as the absorption coefficient of quantum dots perovskite is high, the photo-current density of thinner films will be relatively higher compared to thicker films. By controlling the concentration of coating solution, post-annealing condition and $\mathrm{TiO}_{2}$ surface modification on the quantum dot PSC, the efficiency of $6.54 \%$ can be achieved at AM $1.5 \mathrm{G} 1$ sun illumination, as presented in Table 6 . Because quantum dot tends to dissolve constantly into the redox electrolyte, one big issue of $\left(\mathrm{CH}_{3} \mathrm{NH}_{3}\right) \mathrm{PbI}_{3}$ quantum dot sensitized solar cell is its stability. It is stable for approximately $10 \mathrm{~min}$ (about 80\% degradation) under continuous irradiation (Im et al., 2011). As shown in Table 7, the performance of the device is extremely well. This device has an eminently reproducible $\mathrm{V}_{\mathrm{OC}}$ and it is in the excess of $1.0 \mathrm{~V}$. The average current density of this short circuit $\left(\mathrm{J}_{\mathrm{SC}}\right)$ is nearly $20 \mathrm{~mA} \mathrm{~cm}{ }^{2}$, with an average PCE of $13.7 \%$ and a very good fill factor of 70\% (Liu and Kelly, 2014).
Impact of Superior Grain Growth and Light Harvesting Properties on PSC Performance

Another approach to improve the efficiency of PSC is by supervising the grain growth and light harvesting properties. The performance of PSC cells made of nanoassembled $\mathrm{TiO}_{2}$ structure dispensed on $\mathrm{TiO}_{2}$ compact layer, integrated with $\mathrm{PbI}_{2}$ or $\mathrm{CH}_{3} \mathrm{NH}_{3} \mathrm{PbI}_{3}$ layers, are shown in Fig. 10. Because of the relatively smoother, nano-grained nature of the surface of $\mathrm{PbI}_{2}$, perovskite crystal size is smaller in case of $\mathrm{TiO}_{2}$ NP. Larger perovskite crystallites also can enhance light scattering and reduce recombination at the $\mathrm{TiO}_{2} / \mathrm{CH}_{3} \mathrm{NH}_{3} \mathrm{PbI}_{3} / \mathrm{HTM}$ interface. Higher amount of $\mathrm{PbI}_{2}$ retained on the $\mathrm{TiO}_{2} \mathrm{NB}$ film can lead to enhanced grain growth of perovskite crystallites in the NB case and result in poor performance. Efficiency improvement using NB cell can be observed in the increment in both $\mathrm{J}_{\mathrm{SC}}$ and $\mathrm{V}_{\mathrm{OC}}$. Performance of the PSC can be enhanced (based on Table 8, efficiency increases about $17 \%$ ) by using NBs, in addition of a striking improvement of the grain size. Larger $\mathrm{V}_{\mathrm{OC}}$ in $\mathrm{NB}$ cell is attributed to the larger $\mathrm{CH}_{3} \mathrm{NH}_{3} \mathrm{PbI}_{3}$ crystal size, which leads to the reduction in the grain boundary density (Tathavadekar et al., 2015).

Table 5. Parameters of perovskites hybrid solar cells supported on solution-processed $\mathrm{CH}_{3} \mathrm{NH}_{3} \mathrm{PbI}_{3-\mathrm{x}} \mathrm{Cl}_{\mathrm{x}}$ films with different thicknesses (Della Gaspera et al., 2015)

Thickness of

\begin{tabular}{lllll}
$\mathrm{CH}_{3} \mathrm{NH}_{3} \mathrm{PbI}_{3-\mathrm{x}} \mathrm{Cl}_{\mathrm{x}}$ layer $(\mathrm{nm})$ & $\mathrm{PCE}(\%)$ & $\mathrm{FF}$ & $\mathrm{V}_{\mathrm{OC}}(\mathrm{V})$ & $\mathrm{J}_{\mathrm{SC}}\left(\mathrm{mA} / \mathrm{cm}^{2}\right)$ \\
\hline $273 \pm 10$ & $4.88 \pm 0.52$ & $61.2 \pm 0.8$ & $0.95 \pm 0.02$ & $8.45 \pm 0.56$ \\
$296 \pm 13$ & $5.64 \pm 0.48$ & $61.8 \pm 0.6$ & $0.93 \pm 0.04$ & $9.82 \pm 0.63$ \\
$365 \pm 18$ & $7.18 \pm 0.47$ & $61.3 \pm 1.0$ & $0.93 \pm 0.04$ & $12.60 \pm 0.75$ \\
$387 \pm 15$ & $8.61 \pm 0.52$ & $62.2 \pm 0.7$ & $0.90 \pm 0.07$ & $15.38 \pm 0.58$ \\
$401 \pm 16$ & $9.84 \pm 0.55$ & $61.0 \pm 0.9$ & $0.93 \pm 0.03$ & $17.34 \pm 0.64$ \\
$468 \pm 14$ & $10.72 \pm 0.48$ & $61.2 \pm 0.8$ & $0.93 \pm 0.04$ & $18.84 \pm 0.59$ \\
$575 \pm 14$ & $11.88 \pm 0.44$ & $63.2 \pm 0.4$ & $0.95 \pm 0.02$ & $19.79 \pm 0.41$ \\
$607 \pm 17$ & $11.82 \pm 0.51$ & $63.7 \pm 0.5$ & $0.93 \pm 0.06$ & $19.96 \pm 0.44$ \\
$668 \pm 21$ & $9.42 \pm 0.45$ & $60.0 \pm 0.7$ & $0.91 \pm 0.06$ & $17.26 \pm 0.69$ \\
\hline
\end{tabular}

Table 6. Performance parameters of quantum dot sensitized PSC with different $\mathrm{TiO}_{2}$ film thickness (Im et al., 2011)

\begin{tabular}{llllll}
\hline $\mathrm{TiO}_{2}$ film thickness & $\mathrm{J}_{\mathrm{SC}}\left(\mathrm{mA} / \mathrm{cm}^{2}\right)$ & $\mathrm{V}_{\mathrm{OC}}(\mathrm{V})$ & $\mathrm{FF}(\%)$ & $\eta(\%)$ & $\mathrm{Area}\left(\mathrm{cm}^{2}\right)$ \\
\hline 3.6 & 15.99 & 0.629 & 0.617 & 6.20 & 0.309 \\
5.5 & 14.31 & 0.616 & 0.589 & 5.19 & 0.284 \\
8.6 & 10.15 & 0.559 & 0.594 & 3.37 & 0.277 \\
\hline
\end{tabular}

Table 7. Performance parameters of PSC with varying $\mathrm{ZnO}$ film thickness (Liu and Kelly, 2014)

\begin{tabular}{llllll}
\hline No of layers & ZnO film thickness & $\mathrm{J}_{\mathrm{SC}}\left(\mathrm{mA} / \mathrm{cm}^{2}\right)$ & $\mathrm{V}_{\mathrm{OC}}(\mathrm{V})$ & $\mathrm{FF}(\%)$ & PCE (\%) \\
\hline 0 & 0 & 16.5 & 0.46 & 31.7 & 2.4 \\
1 & 10 & 18.0 & 0.99 & 62.4 & 11.1 \\
3 & 25 & 20.5 & 1.01 & 69.6 & 14.4 \\
5 & 40 & 18.9 & 1.01 & 70.0 & 13.3 \\
8 & 70 & 18.4 & 1.01 & 69.5 & 12.9 \\
\hline
\end{tabular}

Table 8. Solar cell parameters for the NP and NB cell on PSC (Tathavadekar et al., 2015)

\begin{tabular}{lllll}
\hline Device & $\eta(\%)$ & $\mathrm{FF}(\%)$ & $\mathrm{V}_{\mathrm{OC}}(\mathrm{V})$ & $\mathrm{J}_{\mathrm{SC}}\left(\mathrm{mA} / \mathrm{cm}^{2}\right)$ \\
\hline NB cell & 9.0 & 0.52 & 0.99 & 17.4 \\
NP cell & 7.7 & 0.65 & 0.9 & 13.1 \\
\hline
\end{tabular}




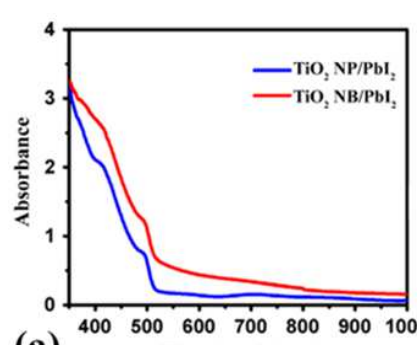

(a)

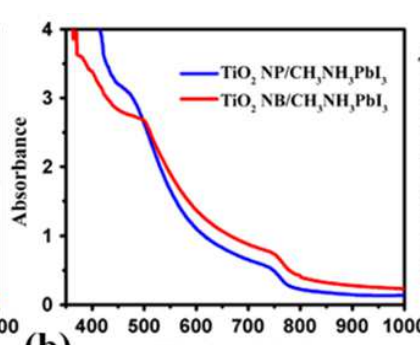

(b)

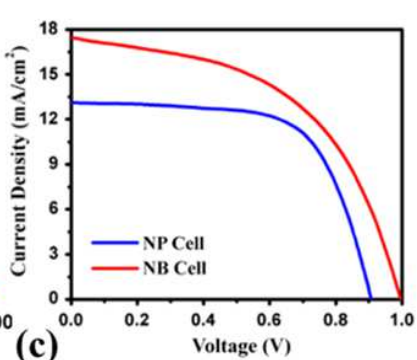

(c)

Fig. 10. UV-vis absorbance spectra of (a) $\mathrm{PbI}_{2}$-loaded and (b) $\mathrm{CH}_{3} \mathrm{NH}_{3} \mathrm{PbI}_{3}$-loaded $\mathrm{TiO}_{2}$ (NP and $\mathrm{NB}$ ) films on FTO substrate respectively (c) J-V characteristic curves for NP cell and NB cell (Tathavadekar et al., 2015)
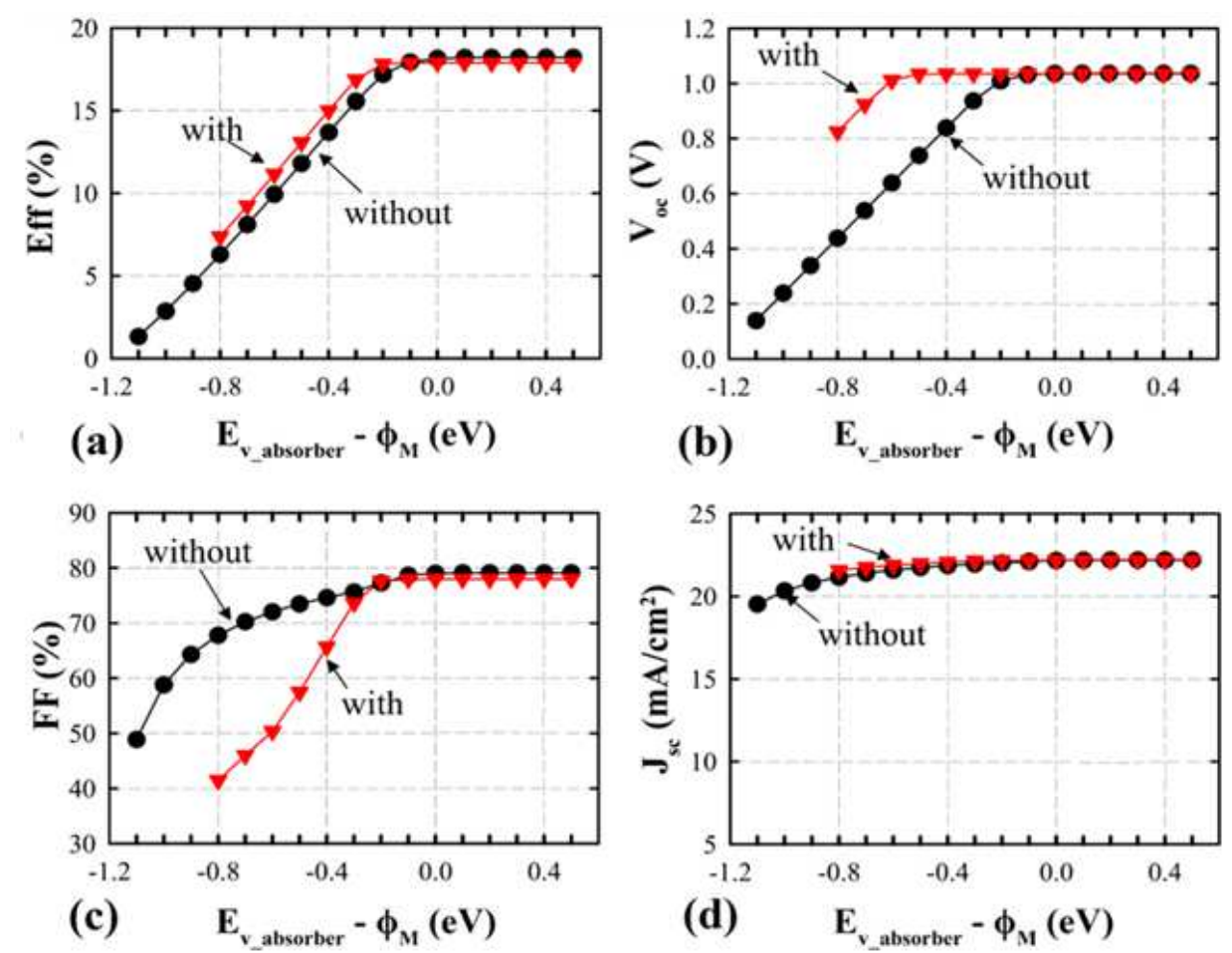

Fig. 11. Parameters of PSCs with and without HTM as a function of $E_{v \_ \text {absorber }}-\phi_{M}$ (Minemoto and Murata, 2014)

Impact of Hole Transport Material (HTM) on PSC Performance

Although HTM can contribute to the efficiency, it cannot resolve the problem of $\phi_{\mathrm{M}}$ mismatching. Presence of the HTM will increase the amount of $\mathrm{V}_{\mathrm{BI}}$ and thus the elimination of HTM is required to preserve the stability of the device. Nonetheless, to achieve a high efficiency, elimination of mesoporous layer is necessary. Improvement of the absorber quality, the matching of $\phi_{\mathrm{M}}$ and back contact material are essential for further improvement of device performance. In open circuit, the monotonical decrease in $\mathrm{V}_{\mathrm{BI}}$ leads to the decrease in the circuit voltage and reduction of electric field across the absorbance. By moving $\phi_{\mathrm{M}}$ upward to vacuum level, both $\mathrm{V}_{\mathrm{OC}}$ and FF will decrease, as shown in Fig. 11. Exclusive of the presence of HTM, the choice of the back contact material is critical in achieving high efficiency. Indicating the $\phi_{\mathrm{M}}$ matching is one of the requirements for achieving high efficiency up to $17.9 \%$ (Minemoto and Murata, 2014).

\section{Impact of Compact Layer (CL) Thickness on PSC Performance}

In this section, the influence of the CL thickness on disparate electron transport path in perovskite is investigated. Generally, increase in the thickness of the CL will improve the performance of the device. Decrease in the area of contact is the reason for the suppression of the electron transport from FTO to HTM and HTM and FTO electrodes form ohmic contacts, leading to the recombination of charge carriers. When the thickness of $\mathrm{CL}$ is increased, $\mathrm{J}_{\mathrm{SC}}, \mathrm{V}_{\mathrm{OC}}$ and $\eta$ of 
device will be increased also. The graph in Fig. 12 indicates that the optimal perovskite performance can be achieved at CL thickness of $90 \mathrm{~nm}$. However, there is a reduction in transparency at $90 \mathrm{~nm} \mathrm{CL}$ and reduction in transmittance at the thickness of $180 \mathrm{~nm}$. Any further increment in the $\mathrm{CL}$ thickness will reduce the recombination retardation and lead to poor performance. Higher optical transmittance allows improvement in absorbance of light, which in turn increases the number of excited electrons. As shown in Table 9, cells with thicker CL have lower current and cells without CL have low energy conversion efficiency.

The CL thickness dependency varies in three sets of fabricated solar cells: FTO/CL/nc$\mathrm{TiO}_{2} /$ Perovskite/HTM/Carbon (1; classical cell), $\mathrm{FTO} / \mathrm{CL} / \mathrm{ncTiO}_{2} /$ Perovskite/Carbon (2; omitting HTM) and $\mathrm{FTO} / \mathrm{CL} /$ Perovskite/HTM/Carbon (3; omitting nc$\mathrm{TiO}_{2}$ ). Figure $12 \mathrm{a}-\mathrm{d}$ present the photovoltaic characteristics of these three sets. The smoothest $\mathrm{TiO}_{2}$ layer is at the thickness of $90 \mathrm{~nm}$ and at the thickness of $180 \mathrm{~nm}$ there will be a decrement in the transmittance, while at $390 \mathrm{~nm}$ there will be $20 \%$ decrement in the transmittance. To achieve a high performance for solar cell, the thickness should be less than $180 \mathrm{~nm}$. A continuous layer can be formed by tightly coating a CL on the FTO (Wang et al., 2014a).

\section{Impact of External Electric Field on Planar Heterojunction PSC Performance}

By operating at a low temperature, planner heterojunction PSC can be fabricated. Figure 13 and 14 illustrate the performance of PSCs under different bias scanning range and different external bias respectively. Performance of this solar cells is strongly reliant on the external bias, while the light soaking effect is inconsequential.

By the appropriate optimization of the bias conditions, power conversion efficiency can be increased by 8 -fold. Besides, PCE can increase significantly from $1 \%$ to over $8 \%$ by applying an external bias prior to the device measurement. Larger scan bias range means better performance (From $0.13 \%$ at -1 to $1 \mathrm{~V}$ to $4.29 \%$ at -1 to $6 \mathrm{~V})$. But when the range is too high (for instance 1 to $8 \mathrm{~V}$ ), the device may get destroyed due to the large injection of current density and eventually, as a result the performance will degrade. Another factor that can lead to decrement in performance is negative bias. On the other hand, positive bias leads to the increase in the performance of PSC. The reproducibility and stability of the device will be increased if ionic transport decreases. There are three possible reasons that can explain the dependency performance on external bias, which are the trap states in perovskite, ferroelectric nature of perovskite and ionic transport in perovskite (Li et al., 2015).

\section{Impact of Blocking Layer on Organic Metal Halide PSC Performance}

To form the blocking layer, titanium precursor solution, which is fabricated either by spin coating, spray pyrolysis or atomic layer deposition, is used. Addition of a compact electron blocking layer will prevent charge recombination originated in FTO and the hole conducting layer, thus ensuring an effective charge. Compact and appropriate thickness of the electron BL can lead to increase in the conductivity and photovoltaic performance. In addition, it can ensure the film uniformity of PSC. For high energy conversion efficiency, a highly compact BL film is very critical. Spin coating the precursor solution of TTIP and then PTA will increase the performance of the solar cell, nevertheless the pinholes within the compact layer will pose negative effect on the performance. As shown in Fig. 15a, the diffraction intensity will be affected if the thickness of the film that is generated by PSP is thicker than that of SP and PS. The device performance will have much improvement (based on Table 10, $\mathrm{J}_{\mathrm{SC}}$ of $12.96 \mathrm{~mA} \mathrm{~cm}{ }^{-2}$ and $\mathrm{V}_{\mathrm{OC}}$ of $0.738 \mathrm{~V}$ together with $\mathrm{FF}$ of $48.77 \%$ ), after performing spin coating of the precursor solution of PTA on the BL film of PS. This will reveal the importance of the $\mathrm{BL}$ in the device. Blocking layer can ensure that an effective charge can be extracted by preventing the hole conducting layer (Jianping et al., 2014).

Table 9. Performance parameters of PSC with varying thickness of compact $\mathrm{TiO}_{2}$ layer (Wang et al., 2014a)

\begin{tabular}{llllll}
\hline No. of spraying cycles & Layer thickness $(\mathrm{nm})$ & $\mathrm{V}_{\mathrm{OC}}(\mathrm{V})$ & $\mathrm{J}_{\mathrm{SC}}\left(\mathrm{mA} / \mathrm{cm}^{2}\right)$ & $\mathrm{PCE}(\%)$ & $\mathrm{FF}(\%)$ \\
\hline 0 & No compact layer & 0.87 & 5.59 & 1.34 & 0.274 \\
2 & 20 & 0.92 & 6.73 & 1.65 & 0.266 \\
4 & 90 & 0.93 & 12.18 & 3.17 & 0.279 \\
10 & 180 & 0.87 & 9.88 & 2.87 & 0.335 \\
20 & 390 & 0.89 & 9.29 & 1.93 & 0.232 \\
\hline
\end{tabular}

Table 10. Photovoltaic parameters of PSCs based on disparate BL films (Jianping et al., 2014)

\begin{tabular}{llllll}
\hline Cell & $\mathrm{V}_{\mathrm{OC}}(\mathrm{V})$ & $\mathrm{J}_{\mathrm{SC}}\left(\mathrm{mA} / \mathrm{cm}^{2}\right)$ & $\eta(\%)$ & $\mathrm{FF}(\%)$ & $\mathrm{RS}(\mathrm{ohm})$ \\
\hline PS & 0.515 & 10.52 & 2.21 & 40.87 & 124.07 \\
SP & 0.709 & 13.32 & 5.51 & 54.57 & 84.04 \\
PSP & 0.738 & 12.96 & 4.66 & 48.77 & 109.57 \\
\hline
\end{tabular}




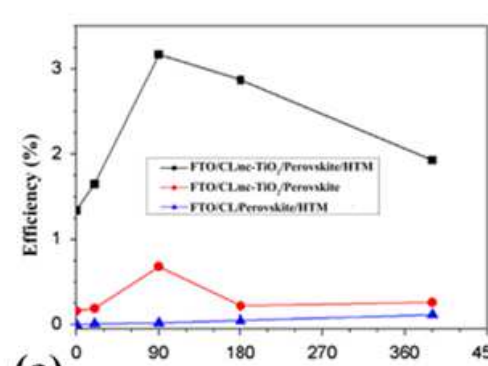

(a) ${ }^{0} \quad{ }^{90} \quad 180 \quad 270 \quad r$ Thickness of compact layer $(\mathrm{nm})$

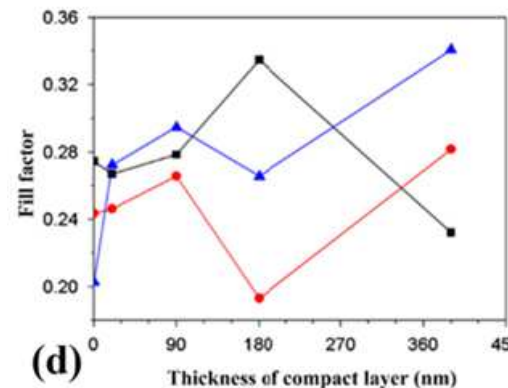

(d)

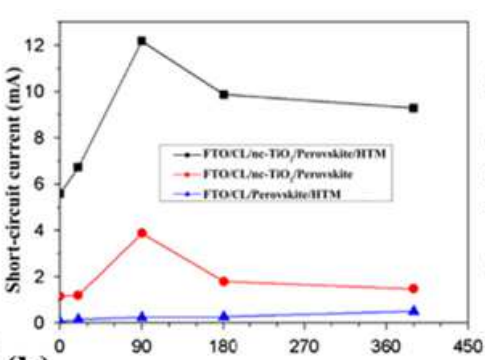

(b)

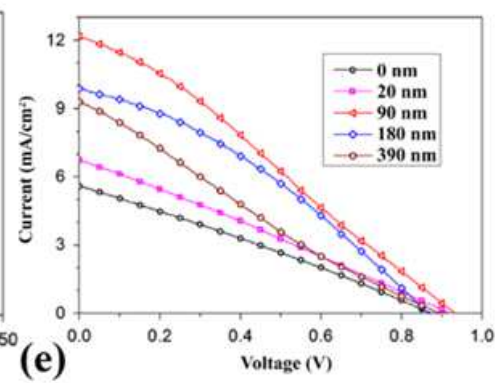

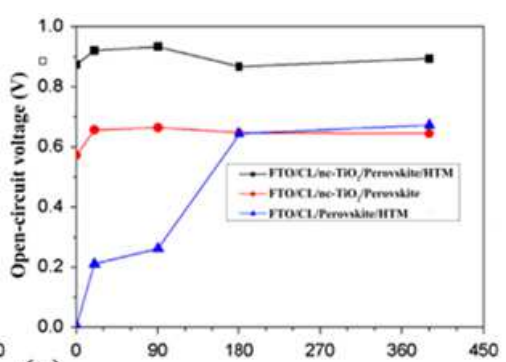

(c) Thickness of compact layer (nm)

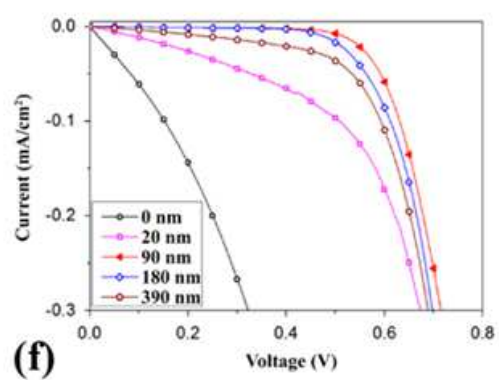

Fig. 12. (a) Power conversion efficiency $(\eta)(b)$ Short-circuit current density $\left(\mathrm{J}_{\mathrm{sc}}\right)(\mathrm{c})$ Open-circuit voltage $\left(\mathrm{V}_{\mathrm{oc}}\right)(\mathrm{d})$ Fill factor $(\mathrm{FF})$, J$\mathrm{V}$ characteristics under (e) Light and (f) dark conditions of PSC containing compact $\mathrm{TiO}_{2}$ layers of different thicknesses (Wang et al., 2014a)
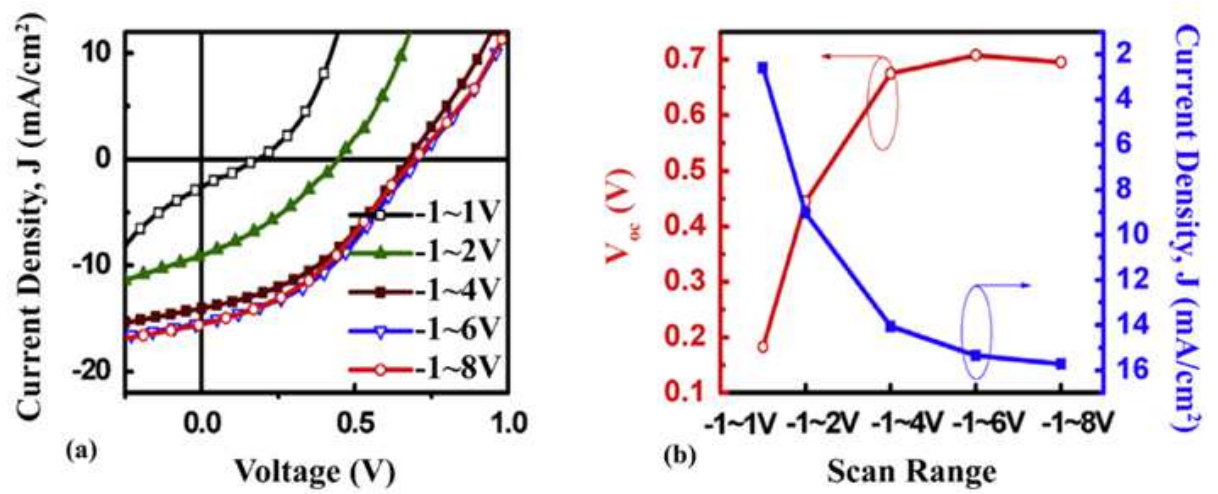

Fig. 13. (a) $\mathrm{J}-\mathrm{V}$ curves and (b) $\mathrm{V}_{\mathrm{OC}}$ and $\mathrm{J}_{\mathrm{SC}}$ values under different scan bias range. The scans are from the positive bias to negative bias (Li et al., 2015)
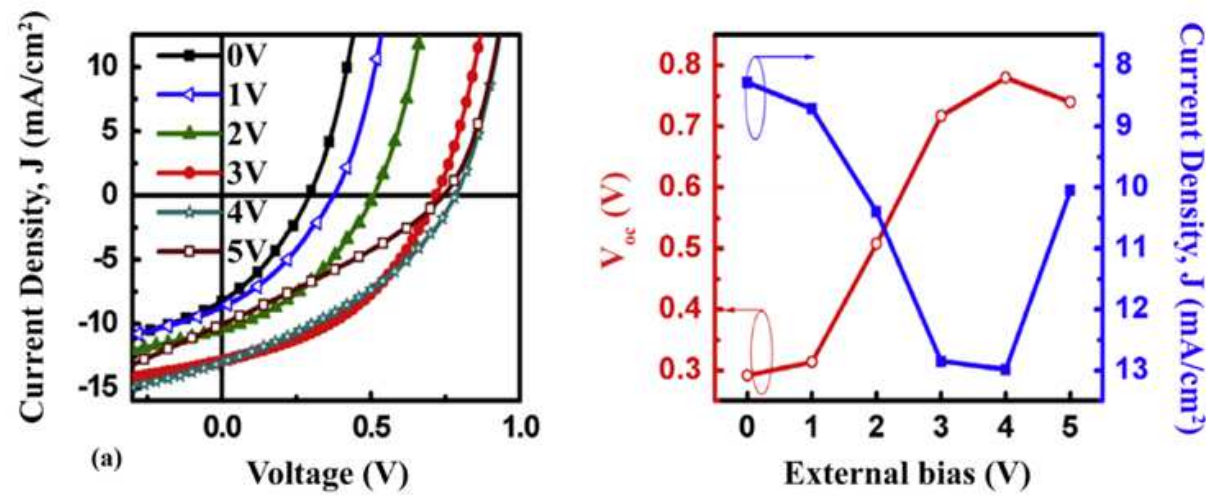

Fig. 14. (a) J-V curves and (b) VOC and JSC values under different external bias for $30 \mathrm{~s}$ using the same scan range ( 0.5 to $1.5 \mathrm{~V})$ (Li et al., 2015) 


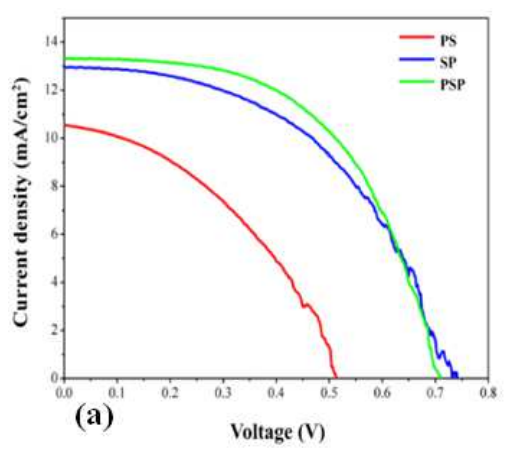

(a)

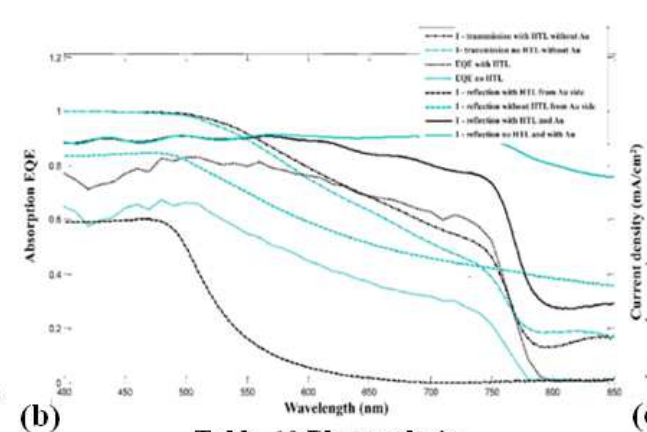

Table 10 Photovoltaic

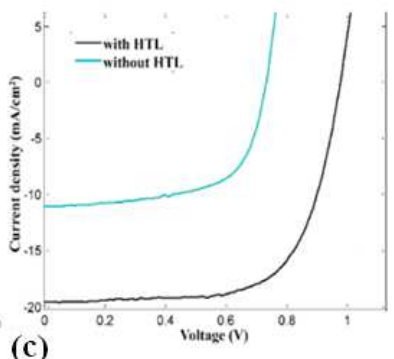

parameters of PSCs

Fig. 15. (a) J-V curves based on different BL films (Jianping et al., 2014) (b) Absorption spectra of a device with and without HTL (c) Current voltage curves of devices with and without HTL (Tress et al., 2014)

\section{Impact of Hole Transparent Layer on PSC Performance}

In this section, the influence of hole transparent layer in $\mathrm{CH}_{3} \mathrm{NH}_{3} \mathrm{PbI}_{3}$ PSC will be discussed. Generally, hole transparent layer is valuable because it exhibits better charge carrier collection efficiency. However, it also increases and decreases $\mathrm{V}_{\mathrm{OC}}$ and recombination respectively. Selectivity of contact in the layer increases due to the recombination at the hole collection electrodes. As shown in Fig. 15b and 15c, at the band edge of perovskite (wavelength 750 to $800 \mathrm{~nm}$ ) absorption will drop strongly, but for the small wavelength (less than $500 \mathrm{~nm}$ ), absorption will decrease gradually. At wavelengths below $500 \mathrm{~nm}$, the absorption is unity for the both PSCs with and without HTL and because of the constant ratio on the EQEs around this wavelength range, the internal quantum efficiency will have to be changed, i.e., charge carrier collection efficiency. For the device without HTL it is decreased by $18 \%\left(3.5 \mathrm{~mA} / \mathrm{cm}^{2}\right)$ (Tress et al., 2014).

\section{Impact of Conduction Band Offset (CBO) and Valence Band Offset (VBO) on PSC Performance}

Interface recombination will become prominent due to the high reduction of activation energy when the valence band energy of absorber layer is higher than the conduction band energy of buffer layer. As a result, the spike formed by the CBO will serve as a fence for photogenerated carrier flow. Figure 16a-d show the performance parameters of PSC with varying CBO, VBO and interface defect density values. High value of $\mathrm{CBO}$ induces double-diode-like curvature and leads to low $\mathrm{FF}$ and stable $\mathrm{V}_{\mathrm{OC}}$. When $\mathrm{CBO}$ decreases from 0.0 to $-0.4 \mathrm{eV}$, fill factor will be decreased while $\mathrm{J}_{\mathrm{SC}}$ remains almost unchanged. Negative $\mathrm{CBO}$ reduces $\mathrm{V}_{\mathrm{OC}}$ and $\mathrm{V}_{\mathrm{OC}}$ corresponding to $\mathrm{E}_{\mathrm{a}}$, however it will increase the interface recombination. From here, open circuit states that the conduction band of the buffer is at least equal or higher than the amount of the absorber.
Low and high VBO have the same hole concentrations, but high VBO means poor FF. Negative VBO decreases both $\mathrm{V}_{\mathrm{OC}}$ and $\mathrm{FF}$, but $\mathrm{J}_{\mathrm{SC}}$ will stay almost unchanged. Increase in VBO will decrease FF and electric field across the absorber. In the similar situation, prominent increase in the interface recombination will happen due to the higher position of the valence band of the HTM in relative to the absorber. Too low position for the valence band of HTM leads to the incomplete depletion of the absorber. Based on the results, the optimum conduction and valence band energy of buffer and HTM are $0.003 \mathrm{eV}$ higher and $0.002 \mathrm{eV}$ lower than the corresponding bands of absorber respectively. These results are essential guidelines in designing new buffer, absorber and HTM (Minemoto and Murata, 2015).

\section{Impact of Heat Treated Films, Ion-Assisted Films and Thermal Annealing on PSC Performance}

Heat treated films and ion assisted films can be used to accelerate the reaction between $\mathrm{CH}_{3} \mathrm{NH}_{3} \mathrm{I}$ and $\mathrm{PbI}_{2}$. By annealing a better crystallinity and high phase purity can be obtained, however with ion assisted greater amorphous structure will be obtained, also different morphologies of grown thin films will be created. Table 11 presents the performance data of PSC with varying annealing time. After heat treating, optical properties, crystallinity and phase purity of the solar cell will increase in more stable film. Phase purity of perovskite can be achieved by only use of ion assisted deposition, without the help of post deposition heat treatment. There is a relation between beam energy and crystallinity of the film, without the ion beam irradiation the crystallinity of film decreases, however the decrease in the beam energy increases the crystallinity of the resultant film. Besides that, by using heat a solar cell with better crystallinity and high phase purity can be achieved, while greater amorphous structure will be achieved with ion assisted process. Different morphologies of grown thin films can also be fabricated (Cimaroli and Yanfa, 2014). In order 
to improve the device performance, the $\mathrm{CH}_{3} \mathrm{NH}_{3} \mathrm{PbBr}_{3} / \mathrm{ZC}-\mathrm{NA}$ composite is annealed at $80^{\circ} \mathrm{C}$. After the thermal annealing, while the $\mathrm{V}_{\mathrm{OC}}$ remains unchanged, there is a slight increase in $\mathrm{J}_{\mathrm{SC}}$ and fill factor and that leads to improvement in averaged $\eta$ (increases from $3.34 \%$ up to $4.31 \%$ under AM 1.5 illumination $\left.\left(100 \mathrm{~mW} / \mathrm{cm}^{2}\right)\right)$. As shown in Fig. $17 \mathrm{a}$, the drop in transmittance at $800 \mathrm{~nm}$ is indicative of the direct band gap of the perovskite. Some of the other effects of thermal annealing are such as stabling the presence of $\mathrm{CH}_{3} \mathrm{NH}_{3} \mathrm{PbBr}_{3}$ crystals and improvement of device performance. Enhancing the crystallinity and reducing the charge recombination will increase the charge transport properties of the perovskite (Boix et al., 2014).
The performance data shown in Table 12 is obtained under one sun illumination $\left(100 \mathrm{mWcm}^{-2}\right)$ at AM1.5 $\mathrm{G}$ condition from $40.26 \mathrm{wt} \%$, using equimolar mixture of $\mathrm{CH}_{3} \mathrm{NH}_{3} \mathrm{I}$ and $\mathrm{PbI}_{2}$ in g-butyrolactone. The electrolyte composition is $0.9 \mathrm{MLiI}, 0.45 \mathrm{MI}_{2}, 0.5 \mathrm{MtBP}$ and 0.05 $\mathrm{M}$ urea in ethyl acetate. Photovoltaic property can be adjusted to certain extent by manipulating the annealing temperature. Photovoltaic performance of $5.5 \mathrm{~mm}$-thick $\mathrm{TiO}_{2}$ layer is slightly improved from voltage of 0.6046 $\mathrm{V}$, photo-current of $13.31 \mathrm{~mA} / \mathrm{cm}^{2}$ and fill factor of 0.5013 to $0.6172 \mathrm{~V}, 13.76 \mathrm{~mA} / \mathrm{cm}^{2}$ and 0.557 respectively, as presented in Table 12 . This improvement is due to the increase of the annealing temperature to $100^{\circ} \mathrm{C}$ (Im et al., 2011).

Table 11. Photovoltaic parameters with varying annealing time on PSC (Song et al., 2015)

\begin{tabular}{lllll}
\hline Annealing time $(\mathrm{min})$ & $\mathrm{J}_{\mathrm{SC}}\left(\mathrm{mA} / \mathrm{cm}^{2}\right)$ & $\mathrm{V}_{\mathrm{OC}}(\mathrm{V})$ & $\mathrm{FF}(\%)$ & $\eta(\%)$ \\
\hline 40 & 19.35 & 0.978 & 68.94 & 13.04 \\
55 & 19.64 & 1.018 & 70.04 & 14.00 \\
70 & 19.37 & 1.033 & 70.37 & 14.08 \\
90 & 19.82 & 1.038 & 71.15 & 13.89 \\
110 & 18.15 & 1.024 & 69.15 & 12.85 \\
\hline
\end{tabular}

Table 12 Influence of annealing temperature on short-circuit performance of quantum dot PSC (Im et al., 2011)

\begin{tabular}{lllllll}
\hline Annealing temperature $\left({ }^{\circ} \mathrm{C}\right)$ & $\mathrm{TiO}_{2}$ film thickness & $\mathrm{J}_{\mathrm{SC}}\left(\mathrm{mA} / \mathrm{cm}^{2}\right)$ & $\mathrm{V}_{\mathrm{OC}}(\mathrm{V})$ & $\mathrm{FF}(\%)$ & $\eta(\%)$ & Area $\left(\mathrm{cm}^{2}\right)$ \\
\hline 40 & 5.5 & 13.31 & 0.605 & 0.513 & 4.13 & 0.265 \\
100 & & 13.76 & 0.617 & 0.557 & 4.73 & 0.267 \\
160 & & 10.06 & 0.627 & 0.588 & 3.71 & 0.303 \\
\hline
\end{tabular}
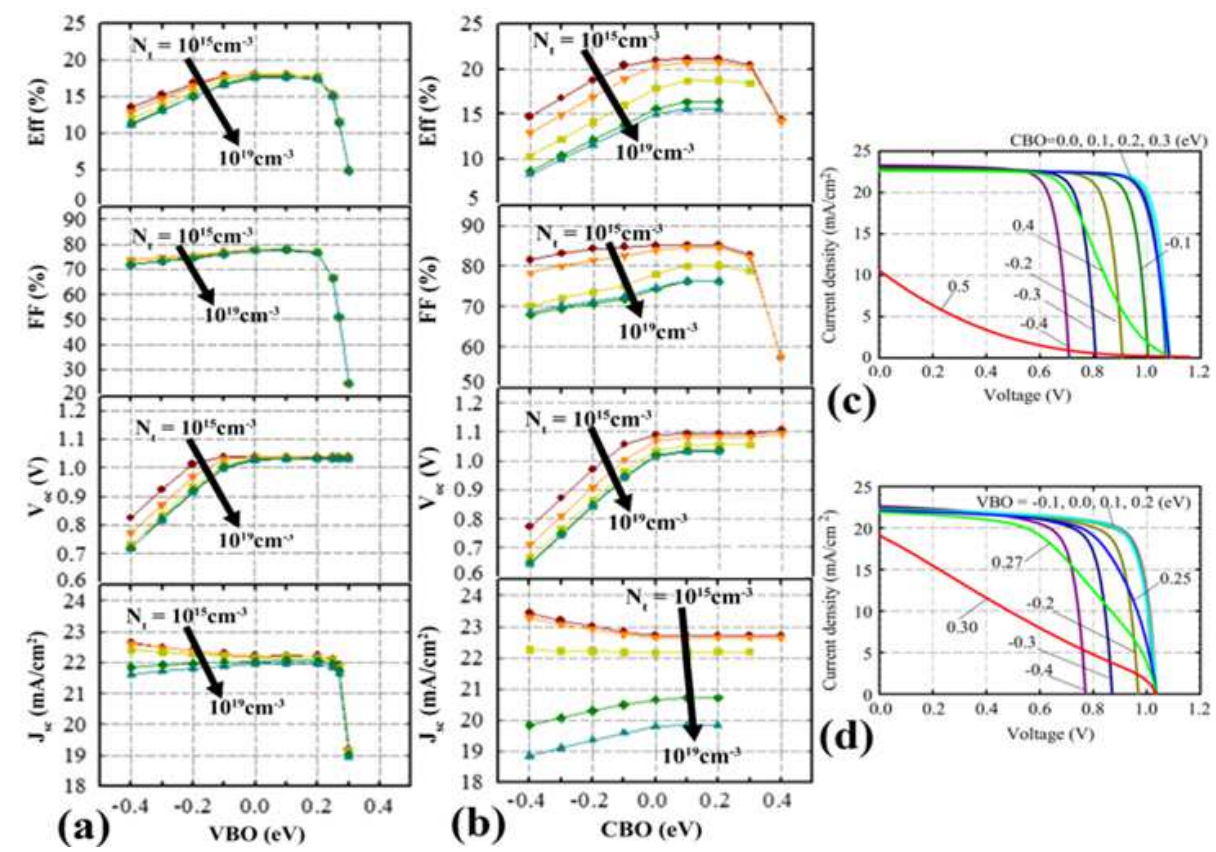

Fig. 16. (a) Parameters of PSC with CBO of the buffer/absorber interface set to zero (b) Parameters of PSC with disparate interface defect densities as a function of CBO of buffer/absorber interface, with VBO of the absorber/HTM interface set to zero (c) J$\mathrm{V}$ curves with the interface defect density of IDL1 set to $10^{16} \mathrm{~cm}^{-3}$ (d) J-V curves of PSC with disparate VBO values of absorber/ HTM interface, with CBO of the buffer/absorber interface set to zero and the interface defect density of IDL2 set to $10^{16} \mathrm{~cm}^{-3}$ (Minemoto and Murata, 2015) 

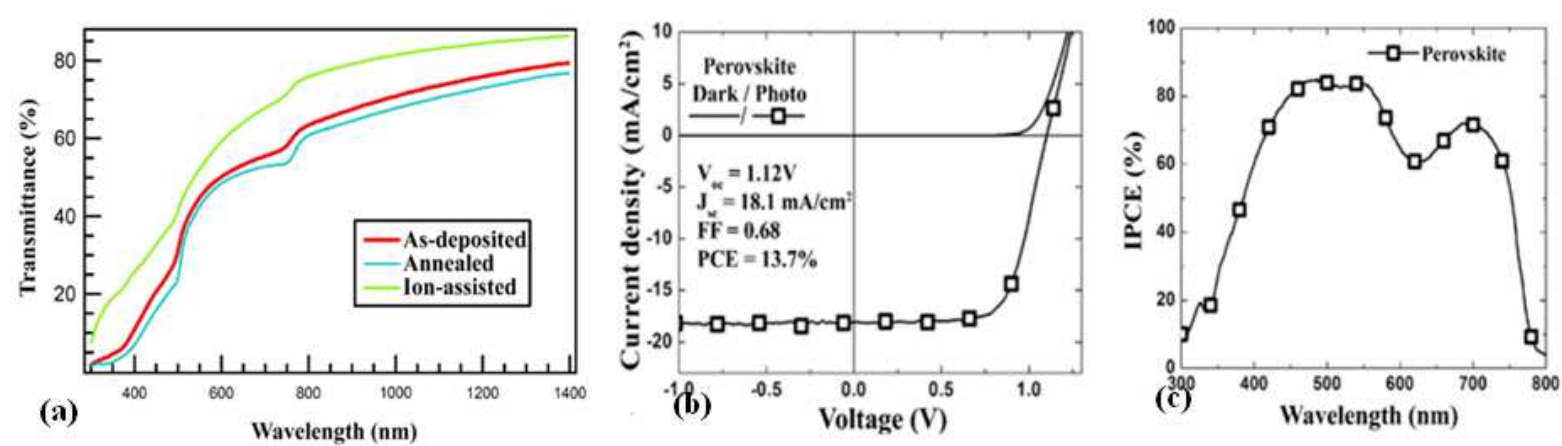

Fig. 17. (a) UV -Vis transmittance spectra of the as-deposited annealed and ion-assisted CH3NH3Pbh thin films (Boix et al., 2014) (b) The J-V characteristic curve and (c) IPCE spectrum of the best performing PSC that employs $\mathrm{MoO}_{3} / \mathrm{NPB}$ layer as hole extraction layer under fully vacuum processing conditions. The scan step of $\mathrm{J}-\mathrm{V}$ characteristics is $0.02 \mathrm{~V}$ with $0.3 \mathrm{~s}$ of interval time for each step and the scan direction is from negative to positive voltage (Kim et al., 2015)

\section{Impact of Buffer Layer on PSC Performance}

The fundamental purpose of the buffer layer is to provide a layer between aqueous solutions for depositing HTM during solar cell preparation and also to absorb photons under photo-illumination. Buffer layer leads to weak light absorbance at the wavelength ranging from 550 to $600 \mathrm{~nm}$ and it will increase $\mathrm{J}_{\mathrm{SC}}$ due to the ignorable attenuation effect. As a result, it can protect the solar cell from contacting with the solution (Liu et al., 2015).

\section{Impact of Varying Environmental Parameters on} PSC Performance

\section{Impact of Air Mass on PSC Performance}

Generally, optical air mass is defined as the optical path length scale for the solar beam over the atmosphere to the optical path over a standard atmosphere at sea level, when sun is at the zenith position. Dry air molecules reduce this ratio to a purely geometrical value. Variation in air mass will lead to amplification or attenuation of solar irradiance, photon density distribution and strong absorption in the visible region. It should be noted that a considerable loss of air mass ratio will occur at AM 1.5. However, high AM will shift the photon distribution into shorter wavelength regions. The blue spectral region is where attenuation of AM is higher and where majority of absorption bands occur. This demonstrates the strict condition imposed by air mass on the performance of PSC (Senthilarasu et al., 2015).

\section{Impact of Aerosol Optical Depth (AOD) on PSC Performance}

The small particles that are suspended in the air are called aerosol. The parameter used in measuring the atmospheric attenuation of solar radiation by aerosol is called the aerosol optical depth. Increase in the AOD will change the incoming irradiance. Due to improvement of turbidity due to increment in AOD, there will be more attenuation and scattering of solar irradiance in the visible UV spectra. The narrow absorption band in the blue wavelength region of the spectrum will be more affected under the turbidity condition. If the aerosol concentration in the atmosphere is low, the spectral losses will be lower than the air mass condition and there will be no effect on the PSC performance (Senthilarasu et al., 2015).

\section{Impact of Perceptible Water on PSC Performance}

The integrated amount of water vapor in zenith direction between the surface and the top of the atmosphere is called perceptible water. To be more precise, the thickness of the liquid water that would be formed if all the vapor in the zenith direction were condensed at the surface of a unit area is also described as the thickness of the liquid water. The improvement in PSC performance by increasing perceptible water, which results in the enhancement of absorption of solar radiation near the infrared spectra, can be observed (Senthilarasu et al., 2015).

\section{Impact of $\mathrm{MoO}_{3} / \mathrm{NPB}$ as Hole Extraction Layers on Fully Vacuum Processed PSC Performance}

Fully vacuum processed PSC will yield better reproducibility. Acceleration in the advancement of the PSCs, high $\mathrm{V}_{\mathrm{OC}}$ and free from the restriction of their solvents are some other benefits of this process. Employing $\mathrm{MoO}_{3} / \mathrm{NPB}$ layer as the hole extraction layer is the main reason which is responsible for the high $\mathrm{V}_{\mathrm{OC}}$. From Fig. 17, the best results that can be achieved under the aforesaid conditions are $13.7 \%$ for PCE, $18.1 \mathrm{~mA} / \mathrm{cm}^{2}$ for JSC, $1.12 \mathrm{~V}$ for $\mathrm{V}_{\mathrm{OC}}$ and 0.67 for FF. In Fig. $17 \mathrm{c}$, the scan step of J-V characteristics is $0.02 \mathrm{~V}$ with $0.3 \mathrm{sec}$ of interval time for each step and the scan direction is from negative to positive voltage. Vacuum processed PSC is a promising tool to apply the various charge transport materials in the layered structures (Kim et al., 2015). 
Impact of Poly (3-Hexylthiophene) Hole Transport Layer on High-Efficiency $\mathrm{CHNHPbI}_{(3-x)} \mathrm{Cl}_{x} \quad P S C$ Performance

One of the suitable HTM choices for high-efficiency PSC is doped P3HT. The performance of the fabricated device can achieve up to $9.3 \%$ PCE and high $\mathrm{V}_{\mathrm{OC}}$. As shown in Fig 18a, the black-colored line represents the absorbance of a dehydrated $\mathrm{TiO}_{2}$ sample, while the darkgray-colored line and the light-gray-colored line represent the absorbance of a UV-treated sample and a sample without any treatment respectively. The $\mathrm{TiO}_{2}$ thickness is $700 \mathrm{~nm}$ and a $40 \% \mathrm{w} / \mathrm{w}$ perovskite precursor solution is spin coated at 2000 RPM and annealed at $120^{\circ} \mathrm{C}$ for $1 \mathrm{~h}$. All measurements are carried out using an integrating sphere. Absorbance of FTO/glass has been subtracted from the absorbance spectra of all the samples. On the other hand, in Fig. 18b, the current density over voltage curves of the best $\mathrm{FTO} / \mathrm{c}-\mathrm{TiO}_{2} / \mathrm{nc}$ $\mathrm{TiO}_{2} / \mathrm{CH}_{3} \mathrm{NH}_{3} \mathrm{PbI} \mathrm{(3-x)}_{\mathrm{x}} \mathrm{Cl}_{\mathrm{x}} / \mathrm{P} 3 \mathrm{HT} / \mathrm{Au}$ (red-colored line and symbols) and $\mathrm{FTO} / \mathrm{c}-\mathrm{TiO}_{2} / \mathrm{nc}-\mathrm{TiO} 2 / \mathrm{CH}_{3} \mathrm{NH}_{3} \mathrm{PbI}_{3-}$ ${ }_{\mathrm{x})} \mathrm{Cl}_{\mathrm{x}} /$ spiro-OMeTAD/Au (black-colored line and symbol) solar cells are presented. The PSC efficiency can be further improved by replacing $\mathrm{Al}_{2} \mathrm{O}_{3}$ with $\mathrm{TiO}_{2}$. Adjusting the perovskite composition through addition of $\mathrm{Br}$ or other elements also serves the same objective (Di Giacomo et al., 2014).

Impact of Reduced Graphene Oxide (RGO) on Highly-Efficient and Stable Planar PSC Performance

RGO nano-sheets are used as electrode interlayer. A highly-efficient and stable $\mathrm{CH}_{3} \mathrm{NH}_{3} \mathrm{PbI}_{3} \mathrm{PSC}$, high RGO conductivity, better aligned energy levels and better growth of the crystalline $\mathrm{CH}_{3} \mathrm{NH}_{3} \mathrm{PbI}_{3}$ can be expected through the addition of the novel RGO HTM. PSCs with RGO have an excellent reproducible efficiency up to $10.8 \%$. Researches have revealed that facilitated charge collection with retarded charge recombination, high RGO conductivity, better aligned energy level and better growth of crystalline $\mathrm{CH}_{3} \mathrm{NH}_{3} \mathrm{PbI}_{3}$ on RGO HTMs are the reasons for improvement in the performance of PSCs with RGO HTM.
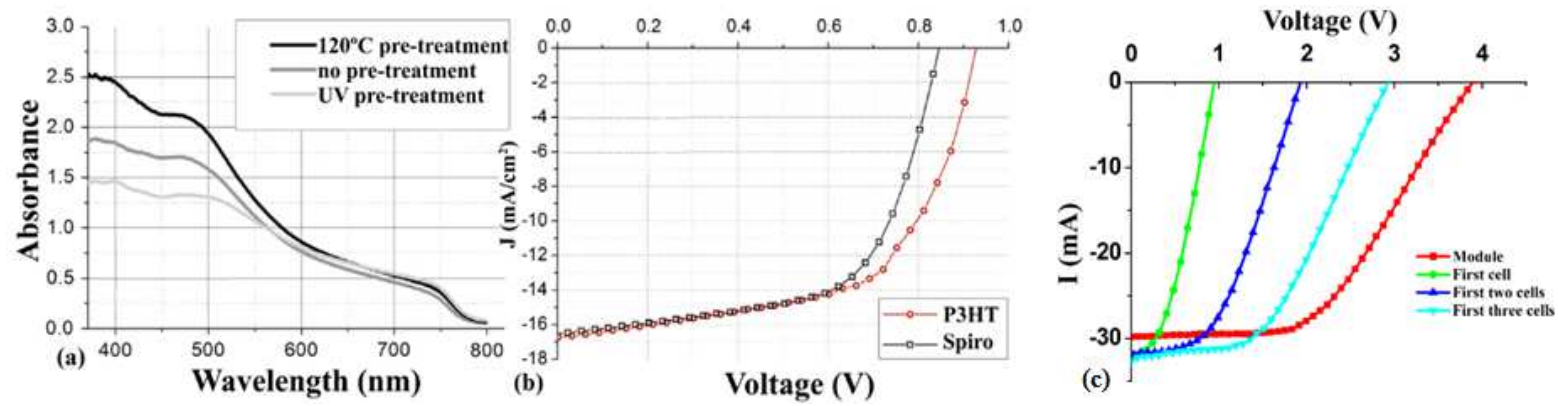

Fig. 18. (a) Absorbance spectra of $\mathrm{TiO}_{2} / \mathrm{CH}_{3} \mathrm{NH}_{3} \mathrm{PbI}_{(3 \mathrm{x})} \mathrm{Clx}$ on FTO glass (b): J-V curves of $\mathrm{FTO} / \mathrm{c}-\mathrm{TiO}{ }_{2} / \mathrm{nc}^{-} \mathrm{TiO}_{2} / \mathrm{CH}_{3} \mathrm{NH}_{3} \mathrm{PbI}{ }_{(3-}$

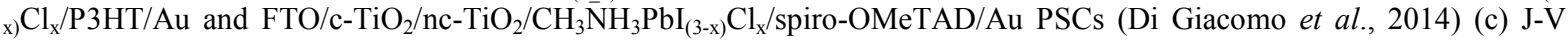
curves of series PSCs prepared by $\mathrm{PbI}_{2}$ blade coating (Razza et al., 2015)
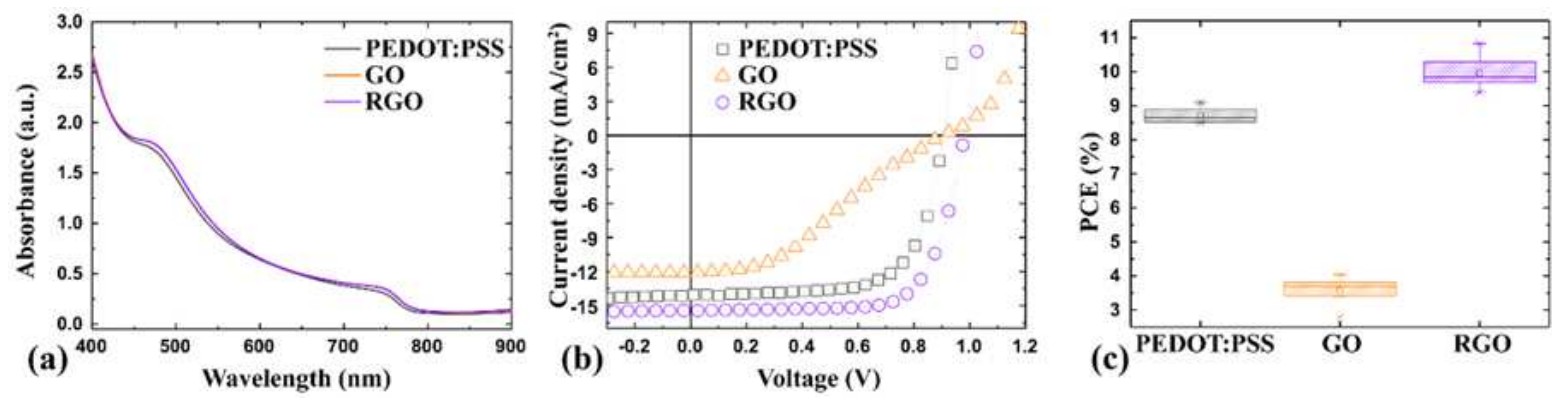

Fig. 19. (a) UV-vis absorption spectra (b) Current over voltage curves for PSC with various HTMs and (c) corresponding PCE statistics based on 20 devices (Yeo et al., 2015)

Table 13. Average performance parameters of PSCs with HTM made of PEDOT: PSS, GO and RGO (Yeo et al., 2015)

\begin{tabular}{llllll}
\hline HTM & $\mathrm{V}_{\mathrm{OC}}(\mathrm{V})$ & $\mathrm{J}_{\mathrm{SC}}\left(\mathrm{mA} / \mathrm{cm}^{2}\right)$ & $\mathrm{PCE}(\%)$ & $\mathrm{FF}(\%)$ & $\mathrm{R}_{\mathrm{s}}\left(\mathrm{ohm} \mathrm{cm}^{2}\right)$ \\
\hline PEDOT: PSS & 0.92 & 13.65 & $8.80(\max .9 .14)$ & 69.97 & 1.10 \\
GO (graphene oxide) & 0.89 & 10.70 & $3.58(\max .4 .04)$ & 37.61 & 3.15 \\
RGO & 0.95 & 14.81 & $9.95(\max .10 .80)$ & 71.13 & 0.92 \\
\hline
\end{tabular}


Table 14. Effect of varying amount of $\mathrm{ZnO}$ nanoparticles in the PSC electrodes on its performance parameters (Lee et al., 2014)

\begin{tabular}{lllll}
\hline Electrode & $\mathrm{V}_{\mathrm{OC}}(\mathrm{V})$ & $\mathrm{J}_{\mathrm{sc}}\left(\mathrm{mA} / \mathrm{cm}^{2}\right)$ & $\eta(\%)$ & $\mathrm{FF}(\%)$ \\
\hline Reference (no modification) & 1.022 & 14.78 & 11.23 & 11.18 \\
10 wt.\%ZnO & 1.027 & 14.56 & 10.92 & 0.73 \\
20 wt.\%ZnO & 1.020 & 14.86 & 11.71 & 0.73 \\
30 wt.\%ZnO & 1.006 & 15.96 & 10.90 & 0.72 \\
40 wt.\%ZnO & 0.993 & 15.24 & 10.58 & 0.71 \\
50 wt.\%ZnO & 0.983 & 15.10 & & 0.70 \\
\hline
\end{tabular}

For example, Table 13 shows a comparison of PSC performance parameters between PSCs with HTM made of PEDOT: PSS, GO and RGO. Figures 19a-c show the performance curves of the three PSCs with varying HTM choices. This approach could motivate future researches into the design and development of HTMs and promise the improvement of PSC technology in terms of having lower cost with higher performance along the excellent stativity (Yeo et al., 2015).

\section{Impact of $\mathrm{PbI}_{2}$ Blade Coating as Air-Flow Assistance on PSC Performance}

Blade coating can be performed in replacement of conventional spin coating to increase the deposition area. Blade coating can even reduce the use of material due to the peculiar compact structure of the $\mathrm{PbI}_{2}$ obtained from blade-coating. To improve the efficiency, a long dipping time (30 min) into the $\mathrm{CH}_{3} \mathrm{NH}_{3} \mathrm{I}$ solution is required. By legitimate boost of the blade deposition and the air flow dynamics over the very large areas, most of the issues related with limited efficiency can be resolved. Figure $18 \mathrm{c}$ represents the current density over voltage characteristic curve of an $8 \mathrm{~cm}^{2}$ module with $6.7 \%$ efficiency and large areas solar cells connected in series, prepared by $\mathrm{PbI}_{2}$ blade coating deposition and $30 \mathrm{~min}$ of dipping in $\mathrm{CH}_{3} \mathrm{NH}_{3}$ I solution. The $\mathrm{V}_{\mathrm{OC}}$ of the complete module is the sum of the $\mathrm{V}_{\mathrm{OC}}$ of each cell, indicating a good connection between the cells. The efficiency based on this PSC is reported to be up to $10.3 \%$ (Razza et al., 2015).

Impact of $\mathrm{ZnO}$ Nanoparticles on $\mathrm{TiO}_{2}$ Thin mpElectrodes for PSC

By manipulating the mixing ratio of $\mathrm{ZnO}$ nanoparticles, the thin $\mathrm{TiO}_{2}$ electrodes for two-step process sensitize for PSC can be modified. Table 14 illustrates the effect of varying amounts of $\mathrm{ZnO}$ nanoparticles in the electrodes on the performance parameters of PSC. The best efficiency result is obtained for the cell with electrodes containing $30 \mathrm{wt} . \% \mathrm{ZnO}$, as depicted by the performance curves of PSCs with nonmodified electrodes and $30 \quad$ wt $\%$ ZnO-modified electrodes shown in Fig. 20b and 20c. On the other hand, as shown in the two-step process in Fig. 20a, after the removal of the $\mathrm{ZnO}$ nanoparticles from the electrode structures, the increased current density is attributed to the facilitated conversion of molecular precursors to perovskite (Lee et al., 2014).
To ensure that the performance results obtained are solely dependent on the modification of the mesoporous electrode, it is necessary to hold all other parameters such as film thickness and post processing steps constant. This method has proven itself as a viable alternative for better improvement of the efficiency vin mesoporous and nanostructured solar cells (Lee et al., 2014).

\section{Impact of Low-Temperature Solution on High- Efficiency and High-Flexibility PSC Performance}

The goal of thin film photovoltaics is to reduce the energy cost in solar panels compared to their silicon model. By using an electron collection layer, one of the highest efficiencies for the solution-processed PSC can be achieved. However, this electron collector layer needs to be sintered at $500^{\circ} \mathrm{C}$. As shown in Table 15 , the photovoltaic parameters of a low cost, solution-based disposition procedure nano-composites of $\mathrm{TiO}_{2}$ nanoparticles and graphene as the electron collection layer in mesosuperstruct PSC, is reported. Figure 21a and b, on the other hand, show the performance curves of the samples compared in Table 15 and the best-performing solar cells in bright and dark conditions respectively. The entire device can be fabricated with temperature less than $150^{\circ} \mathrm{C}$ due to the graphene nano-flakes that will provide superior charge collection in nano-composites. Based on Table 15, the graphene/metal oxide nano-composite has the potential as a low-cost solar cell. A relatively good absorbance for PSC can be achieved even with relatively easy solutionbased process at low temperature using low-cost materials and on top of that the process does not rely on the use of elements in limited supply. Electron collection layers have a critical role in the most efficient thin film of PSC, as they facilitate selective charge collection. CdS, the most common commercial thin film of solar cell, has been in operation for this purpose also. They devote to parasitic absorption in the solar cell. It is necessary to mention that they can prevent leakage and shunting for the currents under reverse bias (Zhong et al., 2015; You et al., 2014).

Impact of Cesium-doped Methylammonium on Light Absorber Hybrid PSC Performance

This goal of Cesium doping is to improve the performance of inverted-type perovskite/fullerene planar heterojunction hybrid solar cells. Base on Table 16, high performance is achieved at $10 \% \mathrm{Cs}$ doping in the $\mathrm{MAPbI}_{3}$ 
perovskite structure, represented by enhancements in the morphology, device efficiency in light absorption and energy difference between the valance band. Because of the increment in the in short-circuit current density and open-circuit voltage) with light absorption in optimal device thickness, shown in Fig. 21c, this device efficiency (with $10 \%$ Cs doped) is improved from 5.51 to $7.68 \%$. Such approach to perovskite design offers the possibility to enhance the performance of conventional perovskite solar cells with n-type titania or alumina layers and to achieve even higher open-circuit voltages by employing tandem device structures (Choi et al., 2014).

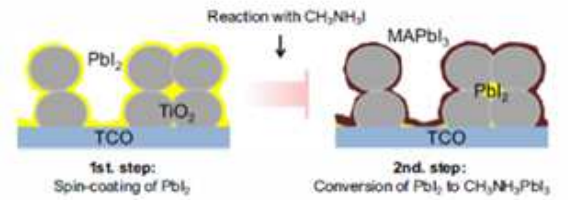

Seheme 1. Two-step process for perovskite layers, An incomplete conversion of $\mathrm{Pbl}_{2}$ (yellow) to $\mathrm{CH}_{3} \mathrm{NH}_{3} \mathrm{Pbl}_{\text {, (dark }}$ brown) occurs when $\mathrm{Pbl}_{2}$ fills in pores completely, which does not contribute to light harvesting.

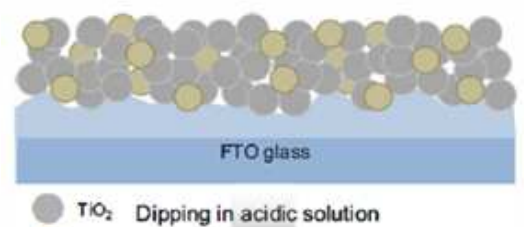

$\mathrm{znO}$

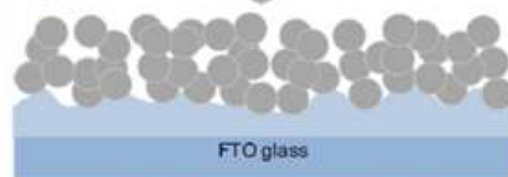

Scheme 2. Illustration for modification of $\mathrm{mp}-\mathrm{TiO}_{2}$ electrode with $\mathrm{ZnO}$ nanoparticles.

(a)
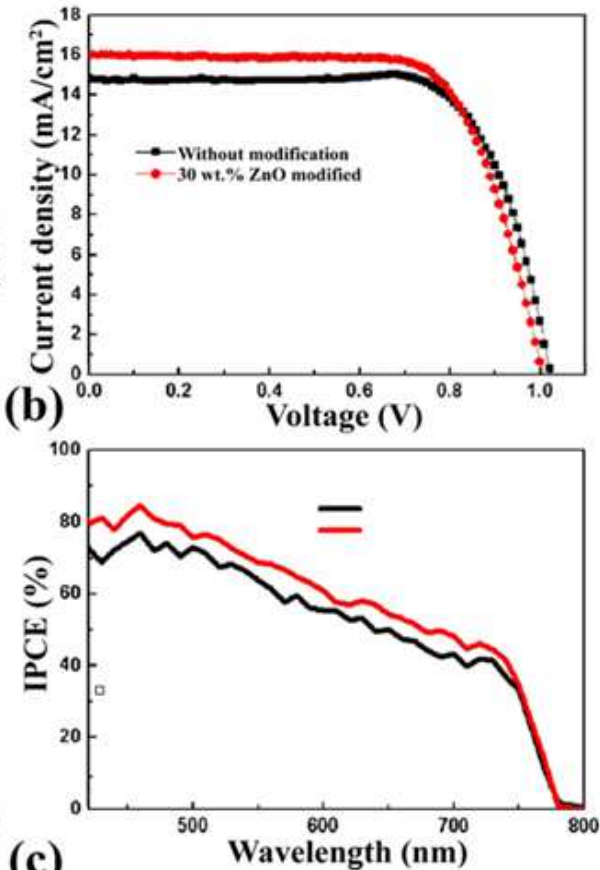

Fig. 20. (a) Schematic diagram of two-step sensitize process to fabricate $\mathrm{ZnO}$-modified $\mathrm{TiO} 2$ electrode for PSC (b) Current density over voltage curves and (c) IPCE curves of cells with unmodified electrode and $30 \mathrm{wt} . \% \mathrm{ZnO}$-modified electrode (Lee et al., 2014)

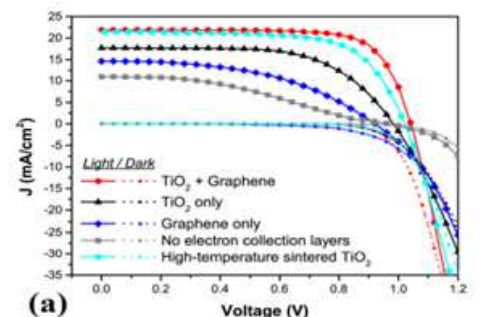

(a)

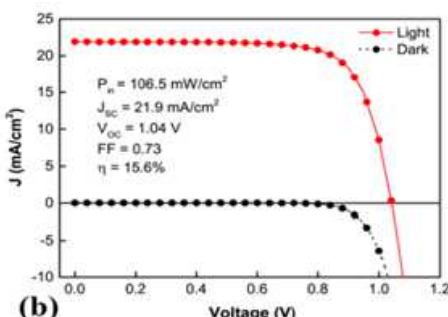

(b)

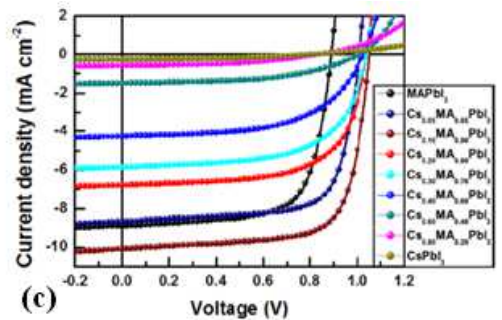

(c) Voltage (V)

Fig. 21. (a) J-V characteristic curves of different electron collection layers under simulated AM 1.5, $100 \mathrm{~mW} / \mathrm{cm}^{2}$ solar irradiation (solid line) and in the dark (dotted line) (b) The best performing $(\eta=15.6 \%)$ solar cell based on a graphene- $\mathrm{TiO}_{2}$ nanocomposites under simulated AM1.5, $106.5 \mathrm{~mW} / \mathrm{cm}^{2}$ solar irradiation (solid line) and in the dark (dotted line), which are processed at temperatures not exceeding $150^{\circ} \mathrm{C}$ (You et al., 2014) (c) J-V characteristic curves of $\mathrm{Cs}_{\mathrm{x}} \mathrm{MA}_{1-\mathrm{x}} \mathrm{PbI}_{3}$ perovskite devices with different Cs ratio (Choi et al., 2014)

Table 15. Best-performing photovoltaics parameters based on disparate electron collection layer under simulated Am 1.5, 106.5 $\mathrm{mW} / \mathrm{cm}^{2}$ solar irradiation (You et al., 2014)

\begin{tabular}{llllll}
\hline Sample & $\mathrm{V}_{\mathrm{OC}}(\mathrm{V})$ & $\mathrm{J}_{\mathrm{SC}}\left(\mathrm{mA} / \mathrm{cm}^{2}\right)$ & $\mathrm{PCE}(\%)$ & $\mathrm{FF}(\%)$ & $\left.\mathrm{R}_{\mathrm{S}} \mathrm{Ohm} . \mathrm{cm}^{2}\right)$ \\
\hline No electron collection layer & 0.95 & 10.8 & 3.7 & 37 & 79.1 \\
$\mathrm{TiO}_{2}$ only & 1.00 & 17.7 & 10.0 & 61 & 10.1 \\
$\mathrm{Graphene} \mathrm{only}^{\mathrm{TiO}}+$ graphene & 0.90 & 14.6 & 5.9 & 48 & 20.3 \\
$\mathrm{High}$ temperature sintered $\mathrm{TiO}_{2}$ & 1.04 & 21.9 & 15.6 & 73 & 4.3 \\
\hline
\end{tabular}


Table 16. Photovoltaic characteristics of $\mathrm{Cs}_{\mathrm{x}} \mathrm{MA}_{1-\mathrm{x}} \mathrm{PbI}_{3} \mathrm{PSC}$ devices with different Cs ratio (Choi et al., 2014)

\begin{tabular}{lllll}
\hline Sample & $\mathrm{V}_{\mathrm{OC}}(\mathrm{V})$ & $\mathrm{J}_{\mathrm{SC}}\left(\mathrm{mA} / \mathrm{cm}^{2}\right)$ & PCE (\%) & $\mathrm{FF}(\%)$ \\
\hline $\mathrm{MAPbI}_{3}$ & 0.89 & 8.89 & 5.51 & 0.70 \\
$\mathrm{Cs}_{0.05} \mathrm{MA}_{0.95} \mathrm{PbI}_{3}$ & 1.01 & 8.69 & 6.29 & 0.72 \\
$\mathrm{Cs}_{0.10} \mathrm{MA}_{0.90} \mathrm{PbI}_{3}$ & 1.05 & 10.10 & 7.68 & 0.73 \\
$\mathrm{Cs}_{0.20} \mathrm{MA}_{0.80} \mathrm{PbI}_{3}$ & 1.04 & 6.76 & 4.58 & 0.65 \\
$\mathrm{Cs}_{0.30} \mathrm{MA}_{0.70} \mathrm{PbI}_{3}$ & 1.04 & 5.85 & 3.78 & 0.62 \\
$\mathrm{Cs}_{0.40} \mathrm{MA}_{0.60} \mathrm{PbI}_{3}$ & 1.03 & 4.26 & 2.50 & 0.57 \\
$\mathrm{Cs}_{0.60} \mathrm{MA}_{0.40} \mathrm{PbI}_{3}$ & 1.01 & 1.50 & 0.79 & 0.52 \\
$\mathrm{Cs}_{0.80} \mathrm{MA}_{0.20} \mathrm{PbI}_{3}$ & 0.84 & 0.58 & 0.22 & 0.46 \\
$\mathrm{CsPbI}_{3}$ & 0.79 & 0.26 & 0.09 & 0.45 \\
\hline
\end{tabular}

Table 17 Comparison of photovoltaic parameters with different sensitizers under AM1.5G simulation condition

\begin{tabular}{|c|c|c|c|c|c|c|}
\hline Material & PCE $(\%)$ & FF & $\mathrm{V}_{\mathrm{OC}}(\mathrm{V})$ & $\mathrm{J}_{\mathrm{SC}}\left(\mathrm{mA} / \mathrm{cm}^{2}\right)$ & Remarks & References \\
\hline Ass-PSSC (PANI $+\mathrm{CH}_{3} \mathrm{NH}_{3} \mathrm{PbI}_{3}+\mathrm{Li}$ salt) & $7.34 \pm 0.06$ & $0.65 \pm 0.03$ & $0.78 \pm 0.03$ & $14.48 \pm 0.06$ & - & Xiao et al. (2014) \\
\hline Ass-PSSC (PANI $\left.+\mathrm{CH}_{3} \mathrm{NH}_{3} \mathrm{PbI}_{3}\right)$ & $5.13 \pm 0.04$ & $0.54 \pm 0.02$ & $0.74 \pm 0.03$ & $12.84 \pm 0.05$ & - & Xiao et al. (2014) \\
\hline Ass-PSSC (PANI only) & $2.06 \pm 0.03$ & $0.36 \pm 0.02$ & $0.57 \pm 0.02$ & $10.06 \pm 0.04$ & - & Xiao et al. (2014) \\
\hline $\mathrm{CH}_{3} \mathrm{NH}_{3} \mathrm{PbI}_{3}$ & 12.7 & 0.68 & 0.98 & 19.1 & - & Yamada et al. (2015) \\
\hline $\mathrm{CH}_{3} \mathrm{NH}_{3} \mathrm{PbI}_{3-\mathrm{x}} \mathrm{Cl}_{\mathrm{x}}+\mathrm{PVP}$ & 8.74 & 0.588 & 0.848 & 17.54 & $3.3 \%$ PVP & Ding et al. (2014) \\
\hline $\mathrm{CH}_{3} \mathrm{NH}_{3} \mathrm{PbI}_{3}$ & 13.6 & $0.58 \pm 0.09$ & $0.988 \pm 0.023$ & $20.4 \pm 0.4$ & $\begin{array}{l}289 \pm 26 \mathrm{~nm} \text { of } \\
\mathrm{CH}_{3} \mathrm{NH}_{3} \mathrm{PbI}_{3-\mathrm{x}} \mathrm{Cl}_{\mathrm{x}}\end{array}$ & $\begin{array}{l}\text { Della Gaspera et al. } \\
\text { (2015) }\end{array}$ \\
\hline Perovskite quantum-dots & 6.2 & 0.617 & 0.629 & 15.99 & - & Im et al. (2011) \\
\hline N719 & 3.89 & 0.611 & 0.700 & 9.10 & - & Im et al. (2011) \\
\hline $\mathrm{CH}_{3} \mathrm{NH}_{3} \mathrm{PbI}_{3-\mathrm{x}} \mathrm{Cl}_{\mathrm{x}}$ & 15.4 & 0.67 & 1.07 & 21.5 & $\begin{array}{l}\text { Vapour deposited } \\
\text { AM1.5 } \\
\left(101 \mathrm{~mW} / \mathrm{cm}^{2}\right)\end{array}$ & Liu et al. (2013) \\
\hline & 8.6 & 0.58 & 0.84 & 0.84 & $\begin{array}{l}\text { Solution processed } \\
\text { AM1.5 } \\
\left(101 \mathrm{~mW} / \mathrm{cm}^{2}\right)\end{array}$ & \\
\hline Submicrometer $\mathrm{TiO}_{2}$ NR sensitized with train ND & 9.4 & 0.63 & 0.955 & 15.6 & $\begin{array}{l}\mathrm{TiO}_{2}-\mathrm{NR}: \\
\mathrm{L}: 0.56 \mu \mathrm{m} \\
\text { Diameter: } 80 \mathrm{~nm}\end{array}$ & Kim et al. (2013) \\
\hline
\end{tabular}

\section{Summary of Various Impacts on PSC Performance}

Besides the sensitizer itself, there are many other factors that influence the PSC efficiency. The sensitizer is only responsible in gaining high efficiency as it only converts the photons into electron-hole pairs. Certain sensitizers can carry out the conversion at certain wavelengths and different sensitizers can have very different recombination rates of electron-hole pairs. To complete the circuit however, the perovskite sensitizer will need to have the electrons and holes to be conducted in opposite directions and into the external circuit. The hole transport material, or HTM, is where the holes will be collected and the electron transport material, or ETM, is where the electrons will be collected. This collection process is crucial to prevent the recombination of electron-hole pairs within the sensitizer itself.

In order to optimize the efficiency through improvement of sensitizers, the focus is mainly on the structure of the sensitizer. The sensitizer is mostly made out of $\mathrm{CH}_{3} \mathrm{NH}_{3} \mathrm{PbI}_{3}$ or mixed-halide $\mathrm{CH}_{3} \mathrm{NH}_{3} \mathrm{PbI}_{3-\mathrm{x}} \mathrm{Cl}_{\mathrm{x}}$ material, fabricated in all-solid-state or combined with $\mathrm{Li}$ salt, or both. Moreover, the sensitizer can also be fabricated alongside with poly-(vinylpyrolidone) (PVP) to improve the efficiency. Table 17 summarizes the performance parameters of PSCs with several different sensitizer materials.

As one can observe in Table 15, HTM, which is to collect the holes generated by the sensitizer, have been shown to have a large impact on the PSC efficiency. Spiro-OMeTAD in PSCs is the most widely used HTM, while P3HT comes second. There are cost concerns when it comes to HTM materials, as spiro-OMeTAD is comparatively costly. Table 18 summarizes the performance parameters of PSCs with several different HTMs.

ETM is used to collect the electrons generated by the sensitizer. As ETM is generally made out of metal oxides, there are many different types of approaches in optimizing the ETM, including annealing and combining the ETM with other materials, or even embedding the sensitizer into the metal oxide itself. Some of the experiments have also shown that coating the sensitizers within the ETM will increase the efficiency and some have taken a different approach, that is to coat the sensitizer on top of a scaffolding $\mathrm{TiO}_{2}$ layer. Table 19 summarizes the performance parameters of PSCs with several different ETMs. 
Table 18 Comparison of photovoltaic parameters with different HTM under AM1.5 simulation condition

\begin{tabular}{lllllll}
\hline Material & PCE $(\%)$ & $\mathrm{FF}$ & $\mathrm{V}_{\mathrm{OC}}(\mathrm{V})$ & $\mathrm{J}_{\mathrm{SC}}\left(\mathrm{mA} / \mathrm{cm}^{2}\right)$ & Remark & References \\
\hline No HTM & 2.74 & 0.48 & 0.62 & 9.22 & - & Nagarjuna et al. (2015) \\
$\mathrm{P} 3 \mathrm{HT}$ & 4.24 & 0.56 & 0.64 & 11.83 & - & Nagarjuna et al. $(2015)$ \\
$\mathrm{D}-\pi$-A conjugated copolymer P & 6.64 & 0.66 & 0.84 & 11.98 & - & Nagarjuna et al. $(2015)$ \\
$\mathrm{P} 3 \mathrm{HT} / \mathrm{CH}_{3} \mathrm{NH}_{3} \mathrm{PbI}_{3-\mathrm{Cl}} \mathrm{Cl}_{\mathrm{x}}$ & 9.3 & $0.58 \pm 0.05$ & $0.93 \pm 0.06$ & $12 \pm 3$ & - & Di Giacomo et al. $(2014)$ \\
Spiro-OMeTAD $/ \mathrm{CH}_{3} \mathrm{NH}_{3} \mathrm{PbI}_{3-\mathrm{x}} \mathrm{Cl}_{\mathrm{x}}$ & 8.6 & $0.60 \pm 0.05$ & $0.84 \pm 0.03$ & $12 \pm 2$ & - & Di Giacomo et al. $(2014)$ \\
$\mathrm{Cu} 2 \mathrm{O}($ simulated result) & - & 0.8397 & 1.276 & 22.75 & Efficiency of $24.40 \%$ & Alharbi et al. $(2014)$ \\
$\mathrm{CuSCN}$ & - & 0.62 & 1.016 & 19.7 & Efficiency of $12.40 \%$ & Alharbi et al. $(2014)$ \\
$\mathrm{NiO}$ & - & 0.75 & 0.936 & 14.9 & Efficiency of $7.30 \%$ & Alharbi et al. $(2014)$ \\
$\mathrm{CuI}]$ & - & 0.60 & 0.550 & 17.8 & Efficiency of $6.00 \%$ & Alharbi et al. $(2014)$ \\
\hline
\end{tabular}

Table 19. Comparison of photovoltaic parameters with different ETM under AM1.5G simulation condition

\begin{tabular}{|c|c|c|c|c|c|c|}
\hline Material & $\begin{array}{l}\mathrm{PCE} / \eta \\
(\%)\end{array}$ & $\mathrm{FF}$ & $\begin{array}{l}V_{\mathrm{OC}} \\
(\mathrm{V})\end{array}$ & $\begin{array}{l}\mathrm{J}_{\mathrm{SC}} \\
\left(\mathrm{mA} / \mathrm{cm}^{2}\right)\end{array}$ & Remarks & References \\
\hline $\mathrm{TiO}_{2}+\mathrm{CH}_{3} \mathrm{NH}_{3} \mathrm{PbI}_{3}$ & 9.7 & 0.62 & 0.888 & 17.6 & - & Kim et al. (2012) \\
\hline Compact-TiO ${ }_{2}$ amorphous & 3.82 & 0.49 & 0.94 & 8.3 & $250^{\circ} \mathrm{C}$; single layer & Yamamoto et al. (2014) \\
\hline \multirow[t]{2}{*}{ Compact- $\mathrm{TiO}_{2}$ anatase } & 1.47 & 0.33 & 0.87 & 5.2 & $450^{\circ} \mathrm{C}$; single layer & Yamamoto et al. (2014) \\
\hline & 5.28 & 0.54 & 0.88 & 11.2 & $450^{\circ} \mathrm{C}$; double layer & \\
\hline Mesoscopic $\mathrm{TiO}_{2}$ & 12 & 0.673 & 0.886 & 19.97 & - & Ramos et al. (2014) \\
\hline Mesoporous $\mathrm{TiO}_{2}+\mathrm{CH}_{3} \mathrm{NH}_{3} \mathrm{PbI}_{3}$ & 12.7 & 0.68 & 0.98 & 19.1 & Embedded & Yamada et al. (2015) \\
\hline $\mathrm{TiO}_{2}$ compact layer & 12.1 & 0.75 & 1 & 17.35 & - & Fakharuddin et al. (2015) \\
\hline $\mathrm{TiCl}_{4}$-nanorods & 12.2 & 0.67 & 0.78 & 22.9 & - & Fakharuddin et al. (2015) \\
\hline \multirow[t]{6}{*}{$\mathrm{TiO}_{2}$-nanocones } & $\eta=9.4$ & 0.63 & 0.955 & 15.6 & $\mathrm{TiO}_{2}$-nanocones at $1580 \mathrm{~nm}$ & Zhong et al. (2015; \\
\hline & 11.0 & 0.6 .5 & 0.92 & 19.5 & $\mathrm{TiO}_{2}$-nanocones at $1400 \mathrm{~nm}$ & Kim et al., 2013) \\
\hline & 10.4 & 0.583 & 0.94 & 19 & $\mathrm{TiO}_{2}$-nanocones at $1100 \mathrm{~nm}$ & \\
\hline & $\eta=7.3$ & 0.62 & 0.929 & 12.6 & $\mathrm{TiO}_{2}$-nanocones at $920 \mathrm{~nm}$ & \\
\hline & 10.3 & 0.552 & 1.02 & 18.4 & $\mathrm{TiO}_{2}$-nanocones at $700 \mathrm{~nm}$ & \\
\hline & $\eta=5.9$ & 0.61 & 0.865 & 11.2 & $\mathrm{TiO}_{2}$-nanocones at $560 \mathrm{~nm}$ & \\
\hline \multirow[t]{2}{*}{$\mathrm{TiO}_{2}+$ Perovskite quantum dots } & 4.73 & 0.557 & 0.617 & 13.76 & Annealing at $100^{\circ} \mathrm{C}$ & Im et al. (2011) \\
\hline & 6.2 & 0.617 & 0.629 & 15.99 & $\mathrm{TiO}_{2} 3.6 \mathrm{~nm}$ thick & \\
\hline ZnO-nanorods & 11.13 & 0.56 & 0.991 & 20.08 & $\begin{array}{l}1 \mu \mathrm{m} \text { long } \\
80 \mathrm{~nm} \text { diameter }\end{array}$ & Son et al. (2014) \\
\hline $\mathrm{TiO}_{2} \rightarrow$ Graphene & 15.6 & 0.73 & 1.04 & 21.9 & $\begin{array}{l}\text { Low temperature } \\
\text { AM1.5 }\left(106.5 \mathrm{~mW} / \mathrm{cm}^{-2}\right)\end{array}$ & Wang et al. (2014b) \\
\hline ZnO-nanodots & 14.4 & 69.6 & 1.01 & 20.5 & Low temperature; $25 \mathrm{~nm}$ thick & Liu and Kelly (2014) \\
\hline $\mathrm{TiO}_{2}$ with embedded $\mathrm{CH}_{3} \mathrm{NH}_{3} \mathrm{PbI}_{3}$ & 15 & 0.73 & 0.993 & 20.0 & AM1.5G $\left(96.4 \mathrm{~mW} / \mathrm{cm}^{-2}\right)$ & Burschka et al. (2013) \\
\hline Mesoporous $\mathrm{ZrO}_{2}$ & 10.8 & 0.59 & 1.07 & 17.3 & - & Bi et al. (2013) \\
\hline $\mathrm{TiO}_{2}$ (TSD) & 9.5 & 0.58 & 0.89 & 18.3 & - & Bi et al. (2013) \\
\hline ITO/PEIE/Y-TiO $2 /$ Perovskite/Spiro-OMeTAD/Au & 19.3 & 0.763 & 1.15 & 22.8 & No reflective coating & Zhou et al. (2014) \\
\hline
\end{tabular}

Table 20. Comparison of photovoltaic parameters with multiple different parameters under AM1.5G simulation condition

\begin{tabular}{|c|c|c|c|c|c|c|}
\hline Material & $\begin{array}{l}\text { PCE } \\
(\%)\end{array}$ & FF & $\begin{array}{l}V_{\text {OC }} \\
(\mathrm{V})\end{array}$ & $\begin{array}{l}\mathrm{J}_{\mathrm{SC}} \\
\left(\mathrm{mA} / \mathrm{cm}^{2}\right)\end{array}$ & Remarks & References \\
\hline $\mathrm{CH}_{3} \mathrm{NH}_{3} \mathrm{PbI}_{3}$ & 7.0 & 0.48 & 0.67 & 21.7 & $\begin{array}{l}\text { 9th day; synthesized } \\
\text { under ambient conditions }\end{array}$ & Sfyri et al. (2015) \\
\hline Mesoporous $\mathrm{TiO}_{2} / \mathrm{CH}_{3} \mathrm{NH}_{3} \mathrm{PbI}_{3} /$ & 0.25 & 0.317 & 0.845 & 0.6 & Copper BM & Tripathi et al. (2015) \\
\hline \multirow[t]{2}{*}{ Graphite/BM } & 0.9 & 0.224 & 0.83 & 4.85 & FTO BM & \\
\hline & 1.11 & 0.445 & 0.702 & 3.56 & Platinium BM & \\
\hline b- $\mathrm{MoO}_{3}$ at transport top electrode & 13.6 & $0.58 \pm 0.09$ & $0.988 \pm 0.023$ & $20.4 \pm 0.4$ & b- $-\mathrm{MoO}_{3}$ at $5 \mathrm{~nm}$ thick & Della Gaspera et al. (2015) \\
\hline $\mathrm{CH}_{3} \mathrm{NH}_{3} \mathrm{PbI}_{3-\mathrm{x}} \mathrm{Cl}_{\mathrm{x}}$ & 14.08 & 0.7039 & 1.033 & 19.37 & Annealed for 70 minutes & Song et al. (2015) \\
\hline Rigid substrate & 11.5 & 0.72 & 0.87 & 18.5 & Glass/ITO substrate & You et al. (2014) \\
\hline Flexible substrate & 9.2 & 0.64 & 0.86 & 16.5 & $\begin{array}{l}\text { PET/ITO substrate } \\
\text { ( } \eta \text { drops after flexing) }\end{array}$ & You et al. (2014) \\
\hline Flexible substrate & 7 & 0.49 & 1.04 & 14.3 & $\begin{array}{l}\mathrm{ETM}=\mathrm{PCBM} \\
\mathrm{HTM}=\text { poly-TPD }\end{array}$ & Roldan-Carmona et al., (2014) \\
\hline Flexible substrate after 50 bends & 6.9 & 0.464 & 1.04 & 14.3 & $\begin{array}{l}\mathrm{ETM}=\text { PCBM } \\
\mathrm{HTM}=\text { poly }-\mathrm{TPD}\end{array}$ & Roldan-Carmona et al., (2014) \\
\hline 200nm-mesoporous $\mathrm{TiO}_{2}$ & 16.46 & 0.76 & 1.105 & 19.58 & 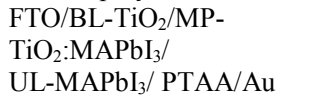 & Jeon et al. (2014) \\
\hline
\end{tabular}

By changing some of the interface materials within the PSC device, the efficiency can change drastically. There are also some other experiments where the substrate has been changed from an ITO substrate/rigid glass to a flexible PET/ITO substrate with a decrease in efficiency. When the flexible substrates are bent or rolled over for multiple times, the efficiency drops. Overall in terms of efficiency, there are a multitude of 
variations in attempting higher efficiency, ranging from optimization of HTM and ETM, fabrication of sensitizer, crystal structure of ETM and how the sensitizer is embedded into the ETM itself. There are even hybrid materials where a combination of materials is used to fabricate the sensitizer.

\section{Conclusion}

Throughout the entire review paper, it can be noted that there are many different influences that will play a part in how perovskite can be manifested into commercial products without losing its properties. There are also many fabrication methods, ranging from commercial-friendly methods to highly sophisticated and costly methods. Some of the low-cost techniques have been tried and tested to fabricate PSC devices, such as spray pyrolysis technique (Razza et al., 2015) and also spin coating of dye-sol paste (Ramos et al., 2014).

With different tables of efficiency based on the variation of how the PSC device is made, it can be foreseen that a combination of said variations can be used to maximize the performance of future PSC. Flexible PSCs have also been fabricated, with a very good efficiency of $6.9 \%$ for a relatively new field (You et al., 2014; Roldan-Carmona et al., 2014). As the PSCs are made out of multiple layers of different materials, these layers, have shown its importance in the device.

We can see that there are certain optimizations done to the PSCs through different trials such as the data shown by Nagarjuna et al. (2015) where only the hole transport material layer is varied and it showed that the layer does indeed play a role in maximizing efficiency. In the sensitizer layer however, it has been said that the liquid electrolytes will pose a problem in the long run as it can potentially leak out or dried over time and thus Xiao et al. (2014) showed that with power conversion of $7.34 \%$, an all-solid-state PSC can be done. The electron transport materials are mostly made out of metal oxides and is shown that the lattice structure of said metal oxide materials can also affect the efficiency drastically, as shown by Yamamoto et al. (2014). However, the fabrication of the ETM alone can incur a high cost onto the device, as sintering is required. Some of the experiments done had the sensitizer embedded into the ETM layer, resulting in an efficiency of $12.7 \%$ (Yamamoto et al., 2014) and some have varied the number of layers of ETM to be fabricated and the resulting efficiency of double-layered ETM reached $5.28 \%$ (Yamamoto et al., 2014).

Perovskite parade attractive and unusual physical properties which has persuaded the world to study it terms of the theoretical modeling and practical applications. Studies on perovskite were able to open the doors to the many revolutionary discoveries, which allowed scientists to design devices with new concepts. Perovskite has a promising future due to low price, adaptability and thermal stability, which often depend on bulk and surface characteristics. The possibility of being coated on flexible or semi-transparent substrate, light weight thin-films are some advantages of PSC. Moreover, having high and rapidly improved efficiencies can also be characterized as advantages of this method. Even though there were many accomplishments on improvement of PSCs, but they are still on early stages of commercialization in compared to their more mature rivals. The main concerns with PSCs are still their steadiness and toxicity. By overcoming these two issues, PSCs can enter the commercial world and even mount among its rivals and become the main commercialized PSCs.

\section{Acknowledgment}

Authors would like to acknowledge Faculty of Engineering, Multimedia University for the support to conduct the review work. Author would also like to acknowledge Ministry of Higher Education (MOHE) to fund the Project under Fundamental Research Grant Schem e FRGS (MMUE150013).

\section{Author's Contributions}

All the Authors listed in this manuscript contributed significantly for the completion of the review article.

Alborz Ehtesham: Drafted the articles.

WongWei Wen: Wrote the critical review portion.

H.Y. Wong: Reviewed the article.

Mukter Zaman: Designed, planned and correspondent this article.

\section{Ethics}

Authors hereby confirming that there is no conflict of interest with this manuscript.

\section{References}

Alharbi, F.H., M.I. Hossain and N. Tabet, 2014. Perovskite based solar cells: A milestone towards cheaper PV technology. Proceedings of the 3rd International Symposium on Environmental Friendly Energies and Applications, Nov. 19-21, IEEE Xplore Press, pp: 1-6. DOI: 10.1109/EFEA.2014.7059955

Bi, D., S.J. Moon, L. Haggman, G. Boschloo and L. Yang et al., 2013. Using a two-step deposition technique to prepare perovskite $\left(\mathrm{CH}_{3} \mathrm{NH}_{3} \mathrm{PbI}_{3}\right)$ for thin film solar cells based on $\mathrm{ZrO}_{2}$ and $\mathrm{TiO}_{2}$ mesostructures. RSC Adv., 3: 18762-18766.

DOI: $10.1039 / \mathrm{C} 3 \mathrm{RA} 43228 \mathrm{~A}$ 
Boix, P.P., K. Nonomura, N. Mathews and S.G. Mhaisalkar, 2014. Current progress and future perspectives for organic/inorganic perovskite solar cells. Mater. Today, 17: 16-23.

DOI: $10.1016 /$ j.mattod.2013.12.002

Bradley, D., 2015. Perovskite promise for solar energy. Mater. Today, 18: 124-125.

DOI: $10.1039 / \mathrm{C} 4 \mathrm{EE} 03322 \mathrm{~A}$

Burschka, J., N. Pellet, S.J. Moon, R. Humphry-Baker and P. Gao et al., 2013. Sequential deposition as a route to high-performance perovskite-sensitized solar cells. Nature, 499: 316-319.

DOI: 10.1038 /nature 12340

Choi, H., J. Jeong, H.B. Kim, S. Kim and B. Walker et al., 2014. Cesium-doped methylammonium lead iodide perovskite light absorber for hybrid solar cells. Nano Energy, 7: 80-85. DOI: $10.1016 /$ j.nanoen.2014.04.017

Cimaroli, A. and Y. Yanfa, 2014. Characterization of ion-assisted, coevaporated $\mathrm{CH}_{3} \mathrm{NH}_{3} \mathrm{PbI}_{3}$ thin films. Proceedings of the IEEE 40th Photovoltaic Specialist Conference, Jun. 8-13, IEEE Xplore Press, pp: 1522-1524.

DOI: 10.1109/PVSC.2014.6925205

Della Gaspera, E., Y. Peng, Q. Hou, L. Spiccia and U. Bach et al., 2015. Ultra-thin high efficiency semitransparent perovskite solar cells. Nano Energy, 13: 249-257. DOI: 10.1016/j.nanoen.2015.02.028

Di Giacomo, F., S. Razza, F. Matteocci, A. D'Epifanio and S. Licoccia et al., 2014. High efficiency $\mathrm{CH}_{3} \mathrm{NH}_{3} \mathrm{PbI}_{(3-\mathrm{x})} \mathrm{Cl}_{\mathrm{x}}$ perovskite solar cells with poly(3-hexylthiophene) hole transport layer. J. Power Sources, 251: 152-156. DOI: 10.1016/j.jpowsour.2013.11.053

Ding, Y., X. Yao, X. Zhang, C. Wei and Y. Zhao, 2014. Surfactant enhanced surface coverage of $\mathrm{CH}_{3} \mathrm{NH}_{3} \mathrm{PbI}_{3-\mathrm{x}} \mathrm{Cl}_{\mathrm{x}}$ perovskite for highly efficient mesoscopic solar cells. J. Power Sources, 272: 351-355. DOI: 10.1016/j.jpowsour.2014.08.095

Dkhissi, Y., F. Huang, S. Rubanov, M. Xiao and U. Bach et al., 2015. Low temperature processing of flexible planar perovskite solar cells with efficiency over 10\%. J. Power Sources, 278: 325-331.

DOI: $10.1016 /$ j.jpowsour.2014.12.104

Fakharuddin, A., F. Di Giacomo, I. Ahmed, Q. Wali and T.M. Brown et al., 2015. Role of morphology and crystallinity of nanorod and planar electron transport layers on the performance and long term durability of perovskite solar cells. J. Power Sources, 283: 61-67. DOI: 10.1016/j.jpowsour.2015.02.084

Ghiasi, M. and A. Malekzadeh, 2014. Solar photocatalytic degradation of methyl orange over $\mathrm{La}_{0.7} \mathrm{Sr}_{0.3} \mathrm{MnO}_{3}$ nano-perovskite. Separat. Purificat. Technol., 134: 12-19.

DOI: $10.1016 /$ j.seppur.2014.07.022
Green, M.A., A. Ho-Baillie and H.J. Snaith, 2014. The emergence of perovskite solar cells. Nat. Photon., 8: 506-514. DOI: 10.1038/nphoton.2014.134

Huang, Y., Y. Wei, S. Cheng, L. Fan and Y. Li et al., 2010. Photocatalytic property of nitrogen-doped layered perovskite $\mathrm{K}_{2} \mathrm{La}_{2} \mathrm{Ti}_{3} \mathrm{O}_{10}$. Solar Energy Mater. Solar Cells, 94: 761-766.

DOI: 10.1016/j.solmat.2009.12.020

Im, J.H., C.R. Lee, J.W. Lee, S.W. Park and N.G. Park, 2011. 6.5\% efficient perovskite quantum-dotsensitized solar cell. Nanoscale, 3: 4088-4093. DOI: $10.1039 / \mathrm{C} 1 \mathrm{NR} 10867 \mathrm{~K}$

Jeon, N.J., J.H. Noh, Y.C. Kim, W.S. Yang and S. Ryu et al., 2014. Solvent engineering for highperformance inorganic-organic hybrid perovskite solar cells. Nat. Mater., 13: 897-903.

DOI: $10.1038 / \mathrm{nmat} 4014$

Jianping, D., L. Jing, W. Minqiang and S. Xiaohui, 2014. The influence of blocking layer on the photovoltaic performance of organometal halide perovskite solar cell. Proceedings of the IEEE 14th International Conference on Nanotechnology, Aug. 18-21, IEEE Xplore Press, pp: 789-793. DOI: 10.1109/NANO.2014.6968104

Kim, B.S., T.M. Kim, M.S. Choi, H.S. Shim and J.J. Kim, 2015. Fully vacuum-processed perovskite solar cells with high open circuit voltage using $\mathrm{MoO}_{3} / \mathrm{NPB}$ as hole extraction layers. Organic Electron., 17: 102-106. DOI: 10.1016/j.orgel.2014.12.002

Kim, H.S., C.R. Lee, J.H. Im, K.B. Lee and T. Moehl et al., 2012. Lead iodide perovskite sensitized all-solidstate submicron thin film mesoscopic solar cell with efficiency exceeding 9\%. Scientific Rep., 2: 591-591. DOI: $10.1038 /$ srep00591

Kim, H.S., J.W. Lee, N. Yantara, P.P. Boix and S.A. Kulkarni et al., 2013. High efficiency solidstate sensitized solar cell-based on submicrometer rutile $\mathrm{TiO}_{2}$ nanorod and $\mathrm{CH}_{3} \mathrm{NH}_{3} \mathrm{PbI}_{3}$ perovskite sensitizer. Nano Lett., 13: 2412-2417. DOI: $10.1021 / \mathrm{nl} 400286 \mathrm{w}$

Lee, Y.H., M. Stefik, L.P. Heiniger, P. Gao and S. Il Seok et al., 2014. Power from the sun: Perovskite solar cells. Proceedings of the IEEE 40th Photovoltaic Specialist Conference, Jun. 8-13, IEEE Xplore Press, pp: 0943-0948. DOI: 10.1109/PVSC.2014.6925068

Li, X., X. Wang, W. Zhang, Y. Wu and F. Gao et al., 2015. The effect of external electric field on the performance of perovskite solar cells. Organic Electron., 18: 107-112. DOI: 10.1016/j.orgel.2015.01.024

Liu, C., Z. Qiu, W. Meng, J. Chen and J. Qi et al., 2015. Effects of interfacial characteristics on photovoltaic performance in $\mathrm{CH}_{3} \mathrm{NH}_{3} \mathrm{PbBr}_{3}$-based bulk perovskite solar cells with core/shell nanoarray as electron transporter. Nano Energy, 12: 59-68. DOI: 10.1016/j.nanoen.2014.12.004 
Liu, D. and T.L. Kelly, 2014. Perovskite solar cells with a planar heterojunction structure prepared using room-temperature solution processing techniques. Nat. Photon., 8: 133-138.

DOI: $10.1038 /$ nphoton.2013.342

Liu, M., M.B. Johnston and H.J. Snaith, 2013. Efficient planar heterojunction perovskite solar cells by vapour deposition. Nature, 501: 395-398. DOI: 10.1038/nature12509

Minemoto, T. and M. Murata, 2014. Impact of work function of back contact of perovskite solar cells without hole transport material analyzed by device simulation. Curr. Applied Phys., 14: 1428-1433. DOI: $10.1016 /$ j.cap.2014.08.002

Minemoto, T. and M. Murata, 2015. Theoretical analysis on effect of band offsets in perovskite solar cells. Solar Energy Mater. Solar Cells, 133: 8-14. DOI: $10.1016 /$ j.solmat.2014.10.036

Nagarjuna, P., K. Narayanaswamy, T. Swetha, G.H. Rao and S.P. Singh et al., 2015. $\mathrm{CH}_{3} \mathrm{NH}_{3} \mathrm{PbI}_{3}$ Perovskite Sensitized Solar Cells Using a D-A Copolymer as Hole Transport Material. Electrochim. Acta, 151: 21-26. DOI: 10.1016/j.electacta.2014.11.003

Ogomi, Y., A. Morita, S. Tsukamoto, T. Saitho and N. Fujikawa et al., 2014. All-solid $\mathrm{Sn} / \mathrm{Pb}$ halide perovskite sensitized solar cells. Proceedings of the IEEE 40th Photovoltaic Specialist Conference, Jul. 8-13, IEEE Xplore Press, pp: 0151-0155.

DOI: 10.1109/PVSC.2014.6925439

Peplow, M., 2014. The Perovskite revolution [News]. IEEE Spectrum, 51: 16-17, 2014. DOI: 10.1109/MSPEC.2014.6840788

Ramos, F.J., D. Cortes, A. Aguirre, F.J. Castano and S. Ahmad, 2014. Fabrication and encapsulation of perovskites sensitized solid state solar cells. Proceedings of the IEEE 40th Photovoltaic Specialist Conference, Jun. 8-13, IEEE Xplore Press, pp: 2584-2587. DOI: 10.1109/PVSC.2014.6925459

Razza, S., F. Di Giacomo, F. Matteocci, L. Cinà and A.L. Palma et al., 2015. Perovskite solar cells and large area modules $\left(100 \mathrm{~cm}^{2}\right)$ based on an air flowassisted PbI2 blade coating deposition process. J. Power Sources, 277: 286-291. DOI: $10.1016 /$ j.jpowsour.2014.12.008

Roldan-Carmona, C., O. Malinkiewicz, A. Soriano, G. Minguez Espallargas and A. Garcia et al., 2014. Flexible high efficiency perovskite solar cells. Energy and Environ. Sci., 7: 994-997. DOI: 10.1039/C3EE43619E

Senthilarasu, S., E.F. Fernández, F. Almonacid and T.K. Mallick, 2015. Effects of spectral coupling on perovskite solar cells under diverse climatic conditions. Solar Energy Mater. Solar Cells, 133: 92-98. DOI: 10.1016/j.solmat.2014.10.037
Sfyri, G., C.V. Kumar, D. Raptis, V. Dracopoulos and P. Lianos, 2015. Study of perovskite solar cells synthesized under ambient conditions and of the performance of small cell modules. Solar Energy Mater. Solar Cells, 134: 60-63.

DOI: 10.1016/j.solmat.2014.11.034

Sheikh, A.D., A. Bera, M.A. Haque, R.B. Rakhi and S.D. Gobbo et al., 2015. Atmospheric effects on the photovoltaic performance of hybrid perovskite solar cells. Solar Energy Mater. Solar Cells, 137: 6-14. DOI: 10.1016/j.solmat.2015.01.023

Son, D.Y., J.H. Im, H.S. Kim and N.G. Park, 2014. 11\% efficient perovskite solar cell based on $\mathrm{ZnO}$ nanorods: An effective charge collection system. J. Phys. Chem. C, 118: 16567-16573. DOI: 10.1021/jp412407j

Song, T.B., Q. Chen, H. Zhou, S. Luo and Y. Yang et al., 2015. Unraveling film transformations and device performance of planar perovskite solar cells. Nano Energy, 12: 494-500.

DOI: 10.1016/j.nanoen.2015.01.025

Tathavadekar, M.C., S.A. Agarkar, O.S. Game, U.P. Bansode and S.A. Kulkarni et al., 2015. Enhancing efficiency of perovskite solar cell via surface microstructuring: Superior grain growth and light harvesting effect. Solar Energy, 112: 12-19. DOI: 10.1016/j.solener.2014.11.016

Tress, W., N. Marinova, O. Inganas, M.K. Nazeeruddin and S.M. Zakeeruddin et al., 2014. The role of the holetransport layer in perovskite solar cells-reducing recombination and increasing absorption. Proceedings of the IEEE 40th Photovoltaic Specialist Conference, Jun. 8-13, IEEE Xplore Press, pp: 1563-1566. DOI: 10.1109/PVSC.2014.6925216

Tripathi, B., P. Bhatt, P. Chandra Kanth, P. Yadav and B. Desai et al., 2015. Temperature induced structural, electrical and optical changes in solution processed perovskite material: Application in photovoltaics. Solar Energy Mater. Solar Cells, 132: 615-622. DOI: 10.1016/j.solmat.2014.10.017

Wang, X., Y. Fang, L. He, Q. Wang and T. Wu, 2014a. Influence of compact $\mathrm{TiO}_{2}$ layer on the photovoltaic characteristics of the organometal halide perovskitebased solar cells. Mater. Sci. Semiconductor Process., 27: 569-576. DOI: $10.1016 /$ j.mssp.2014.07.039

Wang, J.T.W. J.M. Ball, E.M. Barea, A. Abate and J.A. Alexander-Webber et al., 2014b. Lowtemperature processed electron collection layers of graphene $/ \mathrm{TiO}_{2}$ nanocomposites in thin film perovskite solar cells. Nano Lett., 14: 724-730. DOI: $10.1021 / \mathrm{nl} 403997 \mathrm{a}$

Wang, K., C. Liu, P. Du, L. Chen and J. Zhu et al., 2015. Efficiencies of perovskite hybrid solar cells influenced by film thickness and morphology of $\mathrm{CH}_{3} \mathrm{NH}_{3} \mathrm{PbI}_{3-\mathrm{x}} \mathrm{Cl}_{\mathrm{x}}$ layer. Organic Electron., 21: 1926. DOI: $10.1016 /$ j.orgel.2015.02.023 
Wasa, K., I. Kanno, H. Kotera, N. Yamauchi and T. Matsushima, 2016. Thin films of PZT-based ternary perovskite compounds for MEMS. Proceedings of the IEEE Ultrasonics Symposium, Nov. 2-5, IEEE Xplore Press, pp: 213-216. DOI: 10.1109/ULTSYM.2008.0052

Woojun, Y., J.E. Boercker, M.P. Lumb, J.G. Tischler and P.P. Jenkins et al., 2014. Vapor deposition of organic-inorganic hybrid perovskite thin-films for photovoltaic applications. Proceedings of the IEEE 40th Photovoltaic Specialist Conference, Jun. 8-13, IEEE Xplore Press, pp: 1577-1580. DOI: 10.1109/PVSC.2014.6925219

Xiao, Y., G. Han, Y. Chang, H. Zhou and M. Li et al., 2014. An all-solid-state perovskite-sensitized solar cell based on the dual function polyaniline as the sensitizer and p-type hole-transporting material. J. Power Sources, 267: 1-8.

DOI: 10.1016/j.jpowsour.2014.05.053

Xin, F., P. Xiaoli, Z. Shu and X. Yong, 2014. Fabrication of planar heterojunction perovskite solar cells. Proceedings of the International Symposium on Next-Generation Electronics, May 7-10, IEEE Xplore Press, pp: 1-2.

DOI: 10.1109/ISNE.2014.6839359

Yamada, Y., T. Nakamura, M. Endo, A. Wakamiya and Y. Kanemitsu, 2015. Photoelectronic responses in solution-processed perovskite $\mathrm{CH}_{3} \mathrm{NH}_{3} \mathrm{PbI}_{3}$ solar cells studied by photoluminescence and photoabsorption spectroscopy. IEEE J. Photovolta., 5: 401-405. DOI: 10.1109/JPHOTOV.2014.2364115
Yamamoto, K., Z. Ying, T. Kuwabara, K. Takahashi and M. Endo et al., 2014. Low temperature TiOx compact layer by chemical bath deposition method for vapor deposited perovskite solar cells. Proceedings of the IEEE 40th Photovoltaic Specialist Conference, Jun 8-13, IEEE Xplore Press, pp: 1573-1576. DOI: 10.1109/PVSC.2014.6925218

Yeo, J.S., R. Kang, S. Lee, Y.J. Jeon and N. Myoung et al., 2015. Highly efficient and stable planar perovskite solar cells with reduced graphene oxide nanosheets as electrode interlayer. Nano Energy, 12: 96-104. DOI: 10.1016/j.nanoen.2014.12.022

You, J., Z. Hong, Y. Yang, Q. Chen and M. Cai et al., 2014. Low-temperature solution-processed perovskite solar cells with high efficiency and flexibility. ACS Nano, 8: 1674-1680.

DOI: $10.1021 / \mathrm{nn} 406020 \mathrm{~d}$

Zhang, Y., W. Liu, F. Tan and Y. Gu, 2015. The essential role of the poly(3-hexylthiophene) hole transport layer in perovskite solar cells. J. Power Sources, 274: 1224-1230. DOI: 10.1016/j.jpowsour.2014.10.145

Zhong, D., B. Cai, X. Wang, Z. Yang and Y. Xing et al., 2015. Synthesis of oriented $\mathrm{TiO}_{2}$ nanocones with fast charge transfer for perovskite solar cells. Nano Energy, 11: 409-418.

DOI: 10.1016/j.nanoen.2014.11.014

Zhou, H., Q. Chen, G. Li, S. Luo and T.B. Song et al., 2014. Interface engineering of highly efficient perovskite solar cells. Science, 345: 542-546. DOI: $10.1126 /$ science. 1254050 